地 震第 2 輯

第 44 巻特集号（1991）245-263 頁

\title{
マントル対流をめぐる最近の地震学的研究
}

\author{
東京大学理学部地球物理学教室* 末 次 大 輔
}

\section{A Review of Recent Seismological Studies with Implication on Mantle Convection}

\author{
Daisuke Suetsugu \\ Department of Geophysics, Faculty of Science, the University of Tokyo, \\ Yayoi 2-1-16, Bunkyo-ku, Tokyo, 113 Japan \\ (Received November 6, 1989; Accepted December 6, 1990)
}

\begin{abstract}
Our understanding of three dimensional mantle structure has been greatly advanced in the last decade. We review recent seismological studies on the Earth's interior with special emphasis on implication for mantle convection. Studies reviewed in the present paper involve large-scale seismic anisotropy, large-scale mantle heterogeneity, fine structure and topography of the $650 \mathrm{~km}$ discontinuity and the core-mantle boundary, and the slab penetration into the lower mantle.
\end{abstract}

Key words: Three dimensional mantle structure, Mantle convection.

\section{§1.はじめに}

マントル対流がどのようなパターンで起こっているか を知ることは, 現在の地球内部のダイナミクスを知ると いうことにとどまらず，地球誕生以来の地球進化の歴史 を明らかにすることに直結する地球科学上の重大なテー マである. 代表的な対流モデルとしては, 全マントル対 流モデル [例えば, ELSASSER et al.(1979)] と, $650 \mathrm{~km}$ 不連続面を境に上部・下部マントルで別の対流が起こっ ているとする二層対流モデル［例えば MCKENZIE and WEISS (1975)] とがあり (Fig. 1), これらをエンド・メン バーとする様々なモデル [例えば, SiLVER et al. (1988)] が提案されているが，まだ決着には至っていない。

地震学がなし得るのは現在の対流パターンの「スナッ プ・ショット」を推定することである。 マントル対流が 存在すれば, 上昇流の部分は比較的高温で地震波が低速 度となり，下降流の部分では低温で高速度になるだろ う。 上昇流・下降流の存在はマントル境界面や不連続面 の凹凸を誘起し，それが地震波走時に影響するかすしれ ない，また，流れにともなうマントル構成鉱物の結晶格 子の選択配向によって, 地震波速度の伝搬方向に対する

* 个113 東京都文京区弥生 2-11-16 現在, 建設省建築研究所国際地震工学部
依存性（地震波異方性）が生じることが予想される. 従って, 地震波に反映されるこれらの現象を捉えること ができれば, 逆に現在のマントル対流のパターンを推定 することができるだろう。このような可能性が現実に射

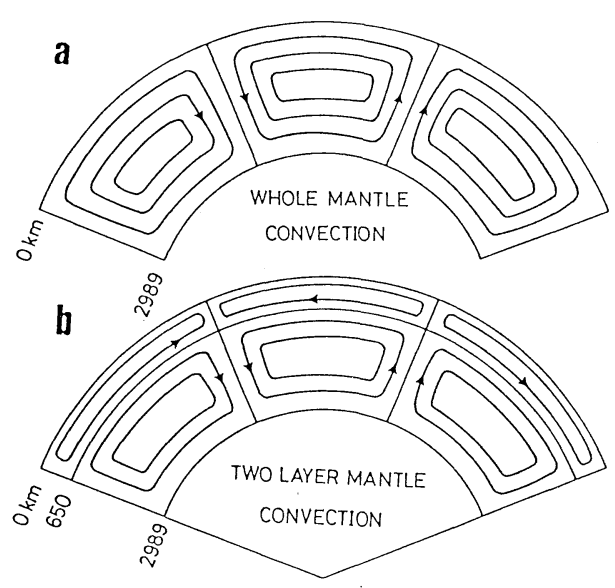

Fig. 1. Cross section of the earth's mantle illustrating the circulation patterns of the mantle convection. (a) Whole mantle convection. (b) Two-layer mantle convection with a boundary at a depth of $650 \mathrm{~km}$. After OLson (1984) with slight modification. 
程に入ってきたのは, 高性能地震観測網の充実や大型計 算機の発達などを背景に 3 次元マントル構造を推定す る研究が大きく進んだ 1980 年代以後である.

本報告では地震波解析によってマントル対流の存在や パターンがどれだけ明らかになってきたかレビューす る. その際次のような 4 種類の研究に大きく分けて議論 する.（1) 地震波異方性；(2) マントル内部の地震波速度 三次元大規模不均質；（3）最下部マントル（ $\mathrm{D}^{\prime \prime}$ 層）や $650 \mathrm{~km}$ 不連続面付近の速度構造や凹凸; (4) スラブ・ペ ネトレーション：(2)〜 (4) は上に述べたマントル内部の 大規模対流パターンに直接関わっている. (1) の研究は 現状では上部マントル異方性のみが研究対象になってい るが，潜在的にはマントル対流の全貎を知る最も有力な 手段となる可能性がある.

本稿では専ら地震学的手法によってマントル対流につ いてどれだけのことがわかってきたかということに焦点 を絞る. 地球内部構造の推定法や得られた結果の詳細に ついては中西 (1988a) や本特集号の中西の論文が，地震 波異方性については川崎 (1988), KAWASAKI (1989), ス ラブ・ペネトレーションについては末次 (1987) に詳し い. また，対流のシミュレーションや物質科学からのア プローチを含めたマントル対流の研究については, 最近 の本多 (1988a)のレビューを参照されたい.

\section{§ 2. 地震波異方性}

マントルを構成する主要鉱物であるオリビンやパイロ キシンなどの単結晶は強い異方性を持っている［例え ば, Kumazawa and Anderson (1969)].これらの鉱物 の結晶格子は，塑性流動などがない状態ではランダムな 方向を向いているので，異方性は観測されない，しかし マントル対流によってマントル物質の結晶格子の選択配 向が起これば，地震観測によって異方性が検出できるか もしれない，海洋上部マントルの塑性流動の「化石」と 考えられているオフィオライト中の超塩基性岩では, 流 動の方向に弾性波速度が最大になるような異方性がみら れる [例えば, NiCORAs et al. (1971)]. 従って, あしこ のような流動パターンと異方性の関係がマントル全体に 適用できるとすると, 地震波異方性の地域分布から逆に 対流パターンを推定できるかも知れない.ここで注意し なければならないのは, 流動が異方性を生み出すメカ二 ズムは複数あり，異方性から一意的にマントル対流パ ターンを決定できるわけではないということである．例 えば異方性が塑性流動に起因する動的再結晶によって生 じる場合，その異方性は対流による応力場を反映するが 必ずしも対流パターン（形状）を表わさない[例えば, KARATO (1989), 竹下・唐戸(1989)]。この問題を解决
するためには, 異方性を作る複数のメカニズムの内のど れがどのような物理的条件の下で重要になるのかを物質 科学的に明らかにすることが必要である [竹下・唐戸 (1989)].

地震波異方性は，その現れ方によって (a) 表面波や $\mathrm{Pn}, \mathrm{Sn}$ 波の方位異方性; (b) レイリー波・ラブ波の分散 から推定される $\mathrm{P}, \mathrm{S}$ 波偏光異方性；(c) S 波のスプリッ ティングの観測によって推定される $\mathrm{S}$ 波偏光異方性の 三つに分けられる.この内 (a) は水平方向に伝搬する表 面波や Pn, Sn の速度が伝搬方向に依存するという現象 で, 直感的に最も理解し易い（b) は，もともとレイリー 波分散曲線から求めた $V_{\mathrm{SV}}$ （SV 波速度）構造とラブ波 分散曲線から求めた $V_{\mathrm{SH}}$ (SH 波速度) 構造が異なると いう現象を説明するために考えられた［例えば，AKI and KAMINUMA (1963)]. これは鉛直・水平 2 方向の振 動に対する媒質の応答 (剛性率) が異なっていることに 対応している. (c) も (b) と同様に振動方向による媒質の 応答の違いによって S 波や $\mathrm{ScS}$ 波に生じる偏光現象で ある. (c) については本特集号で金嶋によって詳しく解 説されているのでここでは省略し，(a),(b), 特に表面波 から観測される大規模異方性に議論を絞る.

80 年代の地震波異方性研究の特徴は次の 2 点である; (1) ディジタル観測網のデータの解析によって, 異方性 の地域分布が明らかになってきた. それに伴い，上部、 ントル異方性と現在あるいは過去のプレート運動との間 に相関があることがはっきりした；(2) 上述の (a)〜 (c) の 地震波異方性を，マントル構成物質の異方性の情報を用 いて統一的に解釈しようとする研究が始まった.

\section{1 方位異方性}

方位異方性の存在自体は, 1960 年代から海洋での屈 折法の結果や表面波の観測［例えば，HESs (1964), ForSYTH (1975)] などから指摘されてきたが，1980年代の 研究の特徴はその地域分布を推定し, プレート運動やマ ントル対流との関係を議論するようになったことであ る. 地域的スケールの研究では, 特に太平洋のレイリー 波速度方位異方性の地域分布が多くの研究者によって推 定された [Montagner (1985), Suetsugu and NAKANishi (1987), NishimURA and Forsyth (1988)]. 太平洋 プレートは約 $40 \mathrm{Ma}$ に拡大方向が変化したので，それ 以前に生成された北西太平洋地域では現在と生成時とで プレート拡大方向が異なると考えられている，異方性が 存在するとして, それが何時のプレート拡大方向と相関 を示すかは興味深いところである. Fig. 2 は NiSHIMURA and Forsyth (1988) によって求められた周期 59 秒の レイリー波最大速度方向である. 彼らの求めた最大速度 方向は地磁気縞模様の方向に直交しており，プレート生 


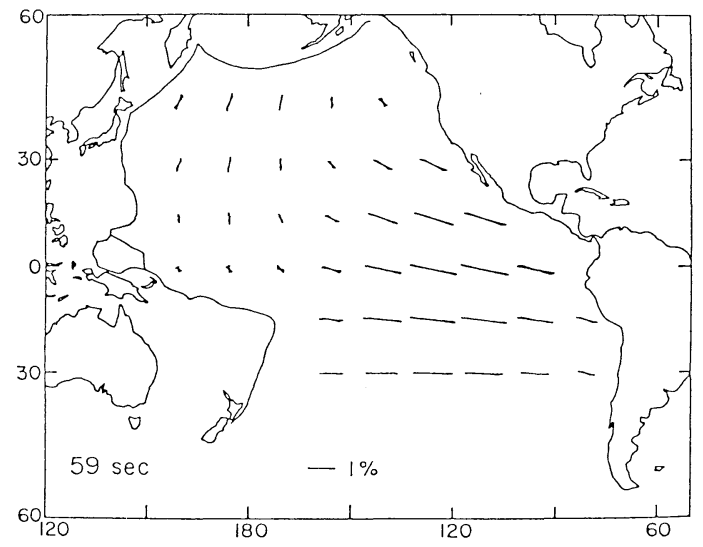

Fig. 2. The azimuthal anisotropy pattern in the Pacific Ocean for Rayleigh wave phase velocities at a period of 59s. The fastest direction of propagation is shown. Length of lines specify velocity difference between the fastest and the slowest directions. After Nishimura and Forsyth (1988).

成時の拡大方向によく一致する. 方位異方性の大きさは 1〜3\% である. この周期のレイリー波はプレートの速 度構造を強く反映するので, これは海嶺付近でオリビン が固化してプレートができたときに，結晶の a 軸がプ レート拡大方向に選択配向し，それが化石として残って いることを示唆する．最近の海底地震観測による Pn 波 の結果むこれを支持している [ShIMAMURA et al. (1983)]. 一方で, MONTAGNer (1985) と Suetsugu and NAKANISHI（1987）はほぼ同じ周期のレイリー波を解析 し, むしろ現在のプレート運動方向に近い最大速度方向 を得ており, NishimURA and FORSYTH (1988) の結果と 矛盾する. 現在・過去のプレート拡大方向が大きく異な る北西太平洋に於てより密な地震観測を行なうことに よってこの問題に決着をつけることができるだろう，ラ ブ波の方位異方性はこれまでほとんど検出されていず, あっても非常に小さいと考えられる [KAWASAKI and Kon'No (1984), Nishimura and Forsyth (1985)].

全地球規模の研究では, TANIMOTO and ANDERSON (1984, 1985) が周期 100 250 秒のレイリ一波方位異方 性を球面調和関数の次数 4 まで求めている. この周期帯 はアセノスフェアの速度構造を強く反映する. 彼らは求 められた最大速度方向とプレート運動から推測されるア セノスフェア内の流れ [HAGER and O'CONNELL (1979)] のパターンとの類似性を指摘した. しかしその後 MoNTAGNER and TANIMOTO (1990) は, デー夕数を大幅に増 やしてレイリー波・ラブ波の位相速度及び方位異方性の 全地球的分布を周期 70〜250 秒にわたって求め, レイ
リー波の最大速度方向とプレート運動方向との相関が強 いことを示している.

以上述べてきた方位異方性は, 表面波の見かけの異方 性であるから，それを生み出す上部マントルの弾性定数 を推定するためには, 見かけ異方性と弾性定数（とその 深さ分布）との関係（偏微分係数）を定式化する必要が ある. 偏微分係数は MAUPIN (1985) や MONTAGNER and NATAF (1986) によって求められている. 彼らの計算に よると, 長周期表面波の方位異方性には上部マントル深 部の異方性だけでなく, マントル最上部の異方性も強く 関係している. 従って, 長周期表面波方位異方性からア セノスフェアの異方性や対流を推定するためには, マン トル最上部の異方性の影響を補正しなければならない. そのためには, Pn 波の異方性データや, 深さ方向の分解 能の良い高次モード表面波データを用いることが必要で ある.

\section{2 レイリー波・ラブ波分散曲線から推定される偏 光異方性}

REGAN and Anderson (1984) は, Transverse Isotropy（鉛直方向に対称軸を持つ六方晶系）を仮定して 太平洋の海洋底年代別の上部マントル速度・異方性構造 を推定した. その結果は, 深さ 100 200 km の低速度 層において太平洋の大部分では $V_{\mathrm{SH}}$ は $V_{\mathrm{SV}}$ よりあ大き いが, 東太平洋海嶺の直下では逆に $V_{\mathrm{Sv}}$ の方が大きい。 彼らはこの結果から, 海嶺付近で上昇流が存在し海嶺か ら離れると水平流が卓越していることを示唆した，彼ら のモデルではプレート内の異方性は弱い，また彼らのモ デルの一番の特徴は海洋プレートの平均的厚さが 50 $\mathrm{km}$ と従来考えられてきた $100 \mathrm{~km}$ よりあずっと薄いと いうことである.この厚さは海山の荷重によるプレート の変形から見積られた値と一致する. プレートの厚さを めぐる議論は川崎 (1988) に詳しい.

NATAF et al. (1986) は, 長周期表面波データを用い, 同様に Transverse Isotropy を仮定して全地球の上部 マントル・モデルをインバージョンによって求めた. 彼 らの求めた異方性分布でもやはり海嶺付近の低速度層で は $V_{\mathrm{Sv}}>V_{\mathrm{SH}}$, また島弧付近であ $V_{\mathrm{Sv}}>V_{\mathrm{SH}}$ となり，プ レート生成及び沈み込みの地域の多くでマントル物質の 上昇や下降流が起きていることを示唆している (Fig. 3). 他の場所では大体 $V_{\mathrm{SH}}>V_{\mathrm{SV}}$ である. 彼らの用いたデー 夕は長周期基本モードなので, 異方性の深さ分布につい ての分解能は乏しい.

深さ方向の分解能を改善するためには表面波高次モ一 ドをデータに取り入れるのが効果的である。 CARA and LÉVÊQUE (1988) はトンガから北米大陸にかけて太平洋 を横切る表面波の分散曲線を高次モードも含めて求め, 


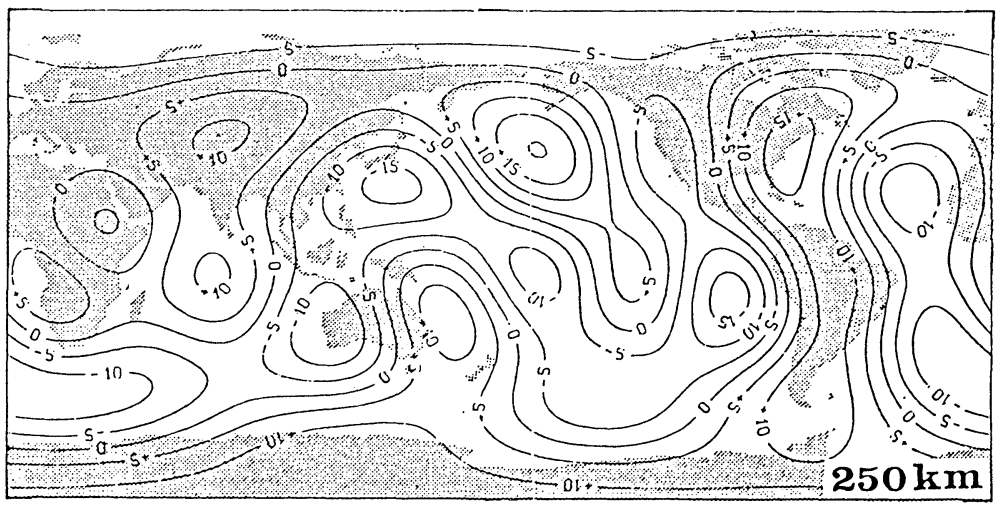

Fig. 3. Map of polarization anisotropy at a depth of $250 \mathrm{~km}$. The contour interval is $5 \%$. Divide by 2 to obtain $\left(V_{\mathrm{SH}}-V_{\mathrm{Sv}}\right) / V_{\mathrm{Sv}}$. After NATAF et al. (1986).

それを深さ方向にインバージョンして異方性の深さ分布 を調べた. その結果, 太平洋下の平均的上部マントルで はプレートも含め深さ $250 \mathrm{~km}$ まで $3 \sim 4 \%$ ほど $V_{\mathrm{SH}}$ が $V_{\mathrm{sv}}$ より大きいことが分かった。

\section{3 表面波方位異方性及び虔光異方性を説明する統} 一的モデル

表面波方位異方性及び偏光異方性から分かってきたこ とをまとめると, (a) 方位異方性の最大速度方向はプ レートの現在あるいは過去の運動方向と関係している.

方位異方性の大きさはレイリー波で 1〜3\%, ラブ波では ほとんど観測されない．(b) 偏光異方性は少なくとも深 さ $200 \sim 300 \mathrm{~km}$ までは存在し, 太平洋の大部分などプ レートの水平運動が起きている場所では $V_{\mathrm{SH}}>V_{\mathrm{Sv}}$, 海 嶺や島弧などマントル物質の上昇やプレートの沈み込み が起きている場所では $V_{\mathrm{Sv}}>V_{\mathrm{SH}}$ となっていること, 異 方性の大きさは $2 \sim 3 \%$ であることが分かった。

表面波方位及び偏光異方性の原因は共に上部マントル での鉱物結晶軸の選択配向にあると考えられるが, 表面 波方位・偏光異方性を同時に説明する異方性マントルモ デルは 80 年代初めまで提出されていなかった. 例えば 偏光異方性の解釈として仮定した Transverse Isotropy は, 対称軸が鉛直方向なので方位異方性を説明すること はできない，そこで近年, 表面波異方性を統一的に説明 する上部マントルの異方性分布を求めようという試みが 始められている. 表面波データだけから 21 個の弾性定 数の 3 次元分布を決定することはできないので, 異方性 の性質を仮定したり (例えば軸対称), 海洋上部マントル の塑性流動の「化石」と考えられているオフィオライト 中の超塩基性岩で測定された異方性デー夕を用いるなど して, 決定すべきモデル・パラメータを少なくしてい る.

KAWASAKI（1986）は，オフィオライト中の超塩基性
岩で測定された異方性を太平洋上部マントルに仮定する ことによって，20〜100 Ma の太平洋におけるレイリー 波・ラブ波平均的分散曲線之平均的方位異方性を統一的 に説明する太平洋の平均的異方性上部マントル・モデル を作った，彼のモデルでは Transverse Isotropy と違 い, 水平かつプレート拡大方向に平行な対称軸をむつ異 方性が仮定されている. 得られたモデルの特徴は以下の 通りである：(1) REGAN and ANDERson (1984) の結果と 同様にプレートの厚さが $45 \mathrm{~km}$ と薄い; (2) プレートと アセノスフェア両方に約 3\% の異方性がある. KAwASAKI（1986）は同じ手法を用いて, 太平洋の年代別異方 性モデルを作ることを試みたが, データをうまく説明す るモデルは得られなかった。これは，異方性の対称軸に ついて施した仮定が, 特に海嶺付近の最む若い地域や島 弧付近の最む古い地域では成り立っていないことを示唆 している.

Nishimura and Forsyth (1989) は彼らの測定した太 平洋での周期 30 120 秒のレイリー波異方性から, 最 大速度方向が過去のプレート運動方向に完全に一致する と仮定した上で年代別の異方性構造をインバージョンに よって求めた. 彼らのモデルでは $80 \mathrm{Ma}$ より若い地域 では少なくとも梁さ $200 \mathrm{~km}$ まで異方性が存在するが, $80 \mathrm{Ma}$ より古い地域では $50 \mathrm{~km}$ までしか存在しない. 彼らはプレートの異方性には過去のプレート運動が, 低 速度層の異方性には現在のプレート運動が関係してお り, $80 \mathrm{Ma}$ より古い地域では両者が異なるために互いに 打ち消し合い，見かけ上浅部までしか異方性が無くなっ てしまったと推論した，すなわち，表面波データを説明 するためには対称軸の方向が水平方向にも深さ方向にも 変化していると考えなければならないことが分かった。

Montagner and Nataf (1988), Montagner and JOBERT (1988) は異方性が軸対称であるという仮定の上 


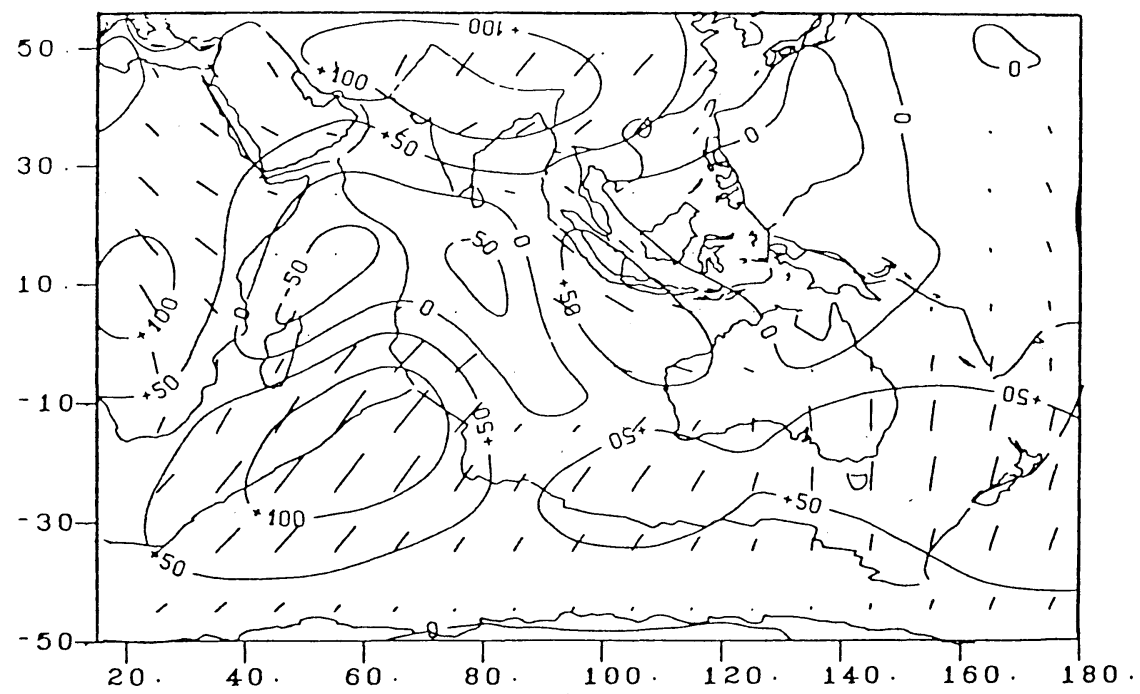

Fig. 4. Map of symmetry axis and amplitude of anisotropy at a depth of $250 \mathrm{~km}$ beneath the Indian Ocean. The contour lines of the amplitude are superimposed to the straight lines indicating horizontal projection of the local symmetry axis. After Montagner and Jobert (1988).

で，対称軸の方向を仮定せずにレイリー波，ラブ波分散 曲線から S 波速度と異方性の大きさ，それに対称軸の方 向ベクトルの 3 次元分布を推定する方法「ベクトリア ル・トモグラフィ」を提唱し, インド洋の上部マントル に適用した. 彼らの求めたモデルでは, 媣さ $100 \mathrm{~km}$ 以 浅で異方性の対称軸が海洋プレート内ではプレート拡大 方向に, 海嶺の下では鉛直方向に, またインドネシアの 沈み込み帯では沈み込み方向に向くなど, プレート運動 に関係すると思われる異方性がみられる. より深部の異 方性は, プレート運動には一致せず，より複雑なパ夕一 ンを示している. Fig. 4 に深さ $250 \mathrm{~km}$ での異方性分布 を示す. 彼らの結果では異方性の対称軸の向きや大きさ は深さによって激しく変化している. MONTAGNER and JOBERT (1988) は表面波基本モードのみを使っているの で深さ方向の分解能には問題があり, このような異方性 の深さ方向の大きな変化が本当であるから゙うかは分から ない. しかし，彼らの手法はマントル対流の三次元パ ターンを推定する道を開いたという意味で大きな意義が ある.

\section{§ 3. マントルの 3 次元大規模不均質構造}

長周期ディジタル地震観测データの蓄積や大容量高速 計算機の発達を背景に, 80 年代にはマントル 3 次元速 度モデルの研究が飛躍的に進んだ（詳細は本特集号の中 西の論文参照). また得られた 3 次元マントル速度モデ ルを基礎データとして用い, ジオイドや熱流量などの観 測データとの比較を通してマントル対流のモデリングを
試みる研究も始まった。

80 年代のマントル大規模不均質構造の研究の特徴は, 地表のテクトニクスの情報を使わずに速度分布を求めて いる点である [例えば, DzIEwONSKI and WoodHouse (1987), Inoue et al. (1990), T ANimoto (1990)]. 70 年代 には, 地表のテクトニクスに従ってあらかじめ地域分け をし, 各地域毎に上部マントル構造を推定する研究が盛 んに行なわれてきた [例えば OKAL (1977)]. しかし, 上 部マントルであ深部になれば地表のテクトニクスと速度 分布に直接の関係があるとは限らないし, 下部マントル となればなおさらなので, 地表のテクトニクス・データ を用いずに不均質モデルを推定することは本質的に重要 である.

これまで求められたモデルは, 細部に多くの不一致が あるが, 長波長の速度不均質パターンは共通している： 浅いところから順に (1) 上部マントルの深さ $300 \mathrm{~km}$ 以 浅は地表のテクトニクスと速度不均質とは強い相関があ る; (2) 上部マントル遷移層（深さ 400〜600 km) では, 西太平洋と南米に大規模な高速度域, 中央太平洋は全体 に低速度域となるような強い長波長（球面調和関数で 2 次）パターンが存在する; (3) 下部マントルは全層にわ たって環太平洋の沈み込み帯に沿って高速度域, 太平洋 中心部は柱状の低速度域というパターンが卓越する (Fig. 5) ほか, アフリカ南部に顕著な低速度域が存在す る.このような下部マントルのリング状高速度域・柱状 低速度域というパターンは, 最近の球款領域での三次元 対流シミュレーションの結果における特徴的パターンで 


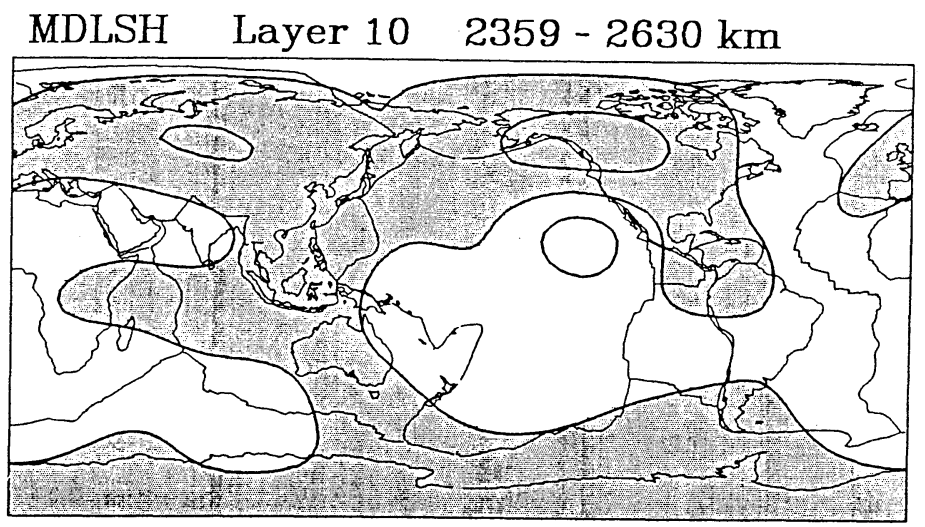

Fig. 5. S-wave velocity map in the depth range between 2,359 and $2,630 \mathrm{~km}$ by a waveform inversion. Dark regions are fast velocity region and white regions are slow. Contour interval is $0.5 \%$. After TANimoto (1990).

あるリング状の下降流域・柱状の上昇流域と良く似てお り [BERCovici et al. (1989)], 地震波から推定された速度 不均質が実際に対流パターンを表現していることを示唆 している. マントル全体を見渡して目に付くのは，沈み 込み帯に沿った高速度異常が上部マントル遷移層から最 下部マントルまで続いていることである。これはマント ル対流の下降流が全マントルにわたって続いていること を示すように見える。しかし他方で，海嶺に沿った低速 度域は深さ $300 \mathrm{~km}$ 以浅でしか見ることができない。 ホット・スポットが多く分布する中央太平洋は下部マン トルでは低速度だが上部マントル $300 \mathrm{~km}$ 以浅では必 ずしも低速度ではないなど，上昇流の方はマントル遷移 層（深さ 400～600 km）を挟んで途切れているかのよ うにみえる。速度不均質モデルだけからマントル全体の 対流パターンを推定するのは一筋縄ではいきそうにな い.これは一つには速度不均質を生じる要因として，マ ントル対流に関係する温度不均質の他に, 化学的不均質 あありうるからである.

地震波速度不均質モデルがマントル対流にともなう温 度不均質でどのように解釈できるかを調べるためには,

熱流量やジオイド・データなどとの比較検討が重要であ る. 地表で測定される熱流量は地下の温度構造を直接反 映しているので, 熱流量デー夕との比較から地震波速度 不均質と温度不均質との関係を調べることができる。 ま た，温度不均質は速度と同様に密度にも影響を与えるの でジオイドとの比較も温度不均質の寄与を確かめるのに 役立つ. 特にジオイド・データの重要性は大きく, 後述 のように, ジオイドと地震波速度不均質モデルとの比較 によってマントル内部の粘性分布やマントルの化学的成 層構造の有無に関する情報を得ることができる.

NAKANISHI and ANDERSON (1984) は, 表面波の位相
速度及び群速度の全地球的な分布を球面調和関数の 6 次の展開係数まで求め, 熱流量の分布 [CHAPMAN and POLLACK (1975)] 之周期 100 250 秒の表面波（特にラ ブ波）速度との間に強い相関があり低速度が高熱流量 に, 高速度が低熱流量に対応していることを示した.こ れは上部マントルの速度不均質が温度不均質と強く関係 していることを示唆している. DzIEWONSKI (1984) は下 部マントルの $\mathrm{P}$ 波速度分布を 6 次まで求めジオイドと 比較した. その結果, 2,3 次で低速度と高ジオイドのパ ターンがよく一致することがわかった。一方ホット・ス ポットの分布 [例えばCHASE (1979)] 62,3 次の下部マ ントルの低速度域とょく一致し, 下部マントル低速度域 が高温のホット・スポットと関連していることを示唆し ている，低速度域では密度も小さくなるので, 高ジオイ ドになるのは一見矛盾しているように見えるが，以下に 述べる Hager らの研究はこれが実は矛盾ではないこと を示した。

Hager らの一連の研究 [HAGER (1984), HAGER et al. (1985), HAGER and CLAYTON (1989)] は, 地球内部の粘 性を考慮に入れ Newton 流体の運動方程式を解くこと によって, マントルの 3 次元速度分布と沈み込むスラブ とからジオイドの長波長成分 (2〜9次) を定量的に説明 できることを示した. 同時にマントルの粘性分布と化学 的成層構造の有無について議論し, マントルに化学的境 界面はないと結論した。 ジオイド計算に用いる三次元密 度分布は三次元速度モデルから推定した. その際, 速度 不均質と密度不均質との間に比例関係を仮定した. 重要 なことは, 密度異常そのもののジオイドへの寄与に加え て, 密度異常に起因する地表面・ $650 \mathrm{~km}$ 不連続面・コ アーマントル境界面 (CMB) などの凹凸のジオイドへの 寄与を考慮した点である．地球は粘性を持っているの 


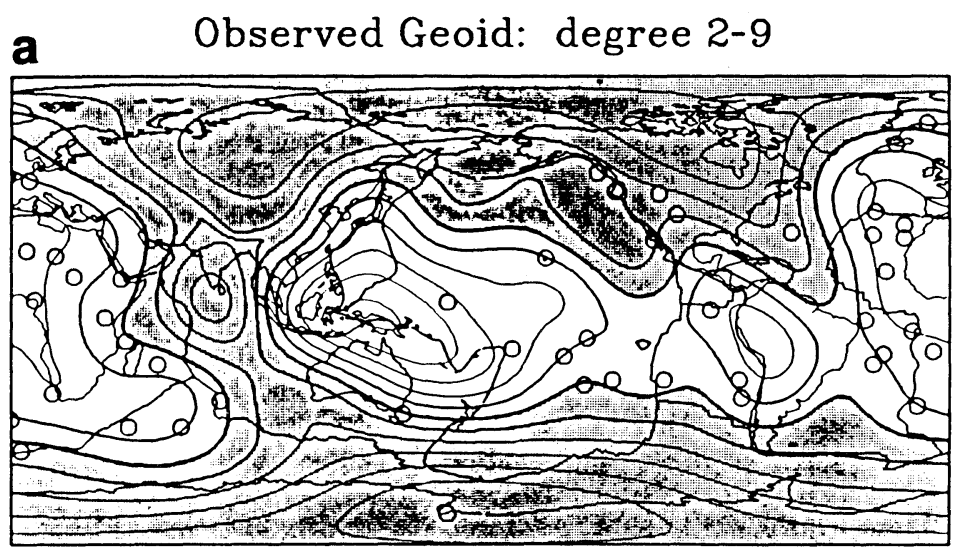

contour interval: $20 \mathrm{~m}$

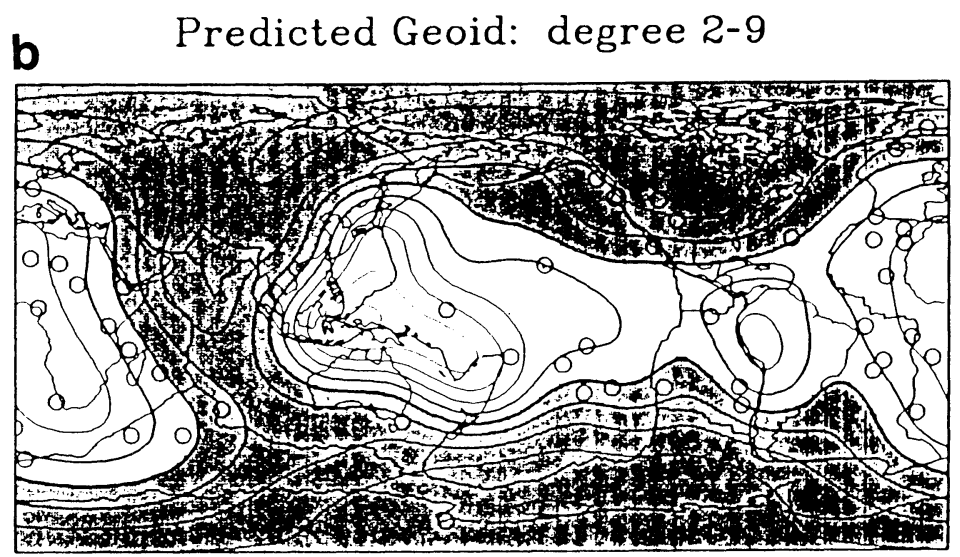

contour interval: $20 \mathrm{~m}$

Fig. 6. Comparison of the observed (a) and the calculated (b) long-wavelength (degree 2-9). Plate boundaries and hotspots (open circles) are also indicated. The contour interval is $20 \mathrm{~m}$ and geoid lows are shaded. After Hager and Clayton (1989).

で，密度コントラストの強い境界面・不連続面の凹凸の 効果を計算に入れるか否かによってジオイドの正負まで 変わってしまう [HAGER (1984)].

HAGER (1984) は沈み込むスラブの密度異常から予測 されるジオイドと人工衛星で観測されるジオイドとを比 較した. スラブによる密度異常分布は和達-Benioff ゾー ンの形状とスラブの密度の見積り值を用いて推定した。 その結果, ジオイドの理論值と観測值とは球面調和関数 の 4〜9 次で一致させることができることを示した. 続 いて HAGER et al. (1985) は, 一見下部マントル速度不均 質モデルと矛盾するように見えるジオイドの 2,3 次成 分が, マントル境界面（地表面・CMB を含む）の凹凸を 考慮に入れることによって符号も含めて非常によく説明 できることを示した. さらに HAGER and CLAYTON (1989) は, 上部マントルに TANIMOTO (1986) の S 波速
度モデル，下部マントルに CLAYTON and COMER (1983) のP波速度モデル，そして HAGER (1984) で用いた沈み 込むスラブによる密度異常を組み合わせ，マントル全体 の密度不均質分布を考慮することによって，2～9 次の ジオイド・パターンの $90 \%$ を説明することに成功した (Fig. 6). Hager らは $650 \mathrm{~km}$ 不連続面が化学的境界面 ではない（言い替えれば全マントル対流）とする方がよ り良くジオイド・データ（特に 4〜9次）を説明すると 主張している. 彼らが最終的に推定した粘性モデルで は, リソスフェアはアセノスフェアと比べて 30 倍粘性 が高く, 下部マントルは上部マントル底部と比ベて 10 倍高い粘性を持つ。彼らはジオイドの理論計算と同時 に，対流による地表面と $\mathrm{CMB}$ の地形，それにマントル 内の流速分布 (Fig. 7) も計算している. Hager らのジオ イド理論計算には, 地球の粘性分布を球対称とするなど 
CC-LM Flow, degree 1-6, at $670 \mathrm{~km}, 100 \mathrm{Myr}$

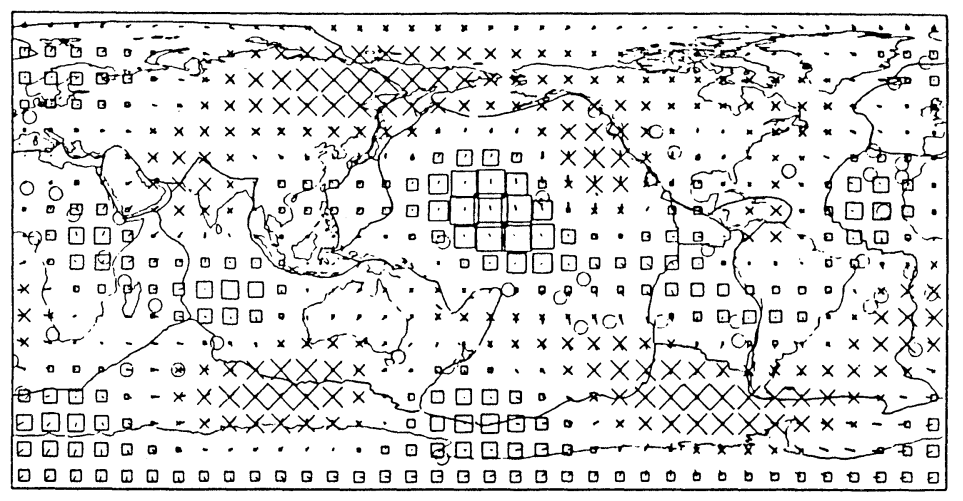

Fig. 7. Flow velocities at a depth of $670 \mathrm{~km}$ driven by the densities inferred from lower mantle tomography. The crosses at the base of each vector represent downwelling, while the boxes indicate upwelling. The size of the symbols and vectors gives the displacement that would occur by extrapolating the flow velocities for $100 \mathrm{Myr}$; touching symbols represent velocities of $1 \mathrm{~cm} / \mathrm{yr}$. Plate boundaries and hotspots (open circles) are also shown. After HAGER and CLAYTON (1989).

の仮定が含まれている．実際には粘性は強い温度依存性 を持つのでこれはかなり強い仮定であり，今後さらに検 討する必要がある，だが，互いに独立な観測量であるジ オイドと地震波速度分布を統一的に説明できることを示 し, マントルの成層構造や粘性に制約を与えた意義は大 きい.

\section{§ 4. マントルの境界面・不連続面付近の構造}

マントルの境界面や不連続面がマントル対流のセルの 境界面に対応しているかどうかを知るためには, 対流セ ルの境界の熱境界層あるいは化学的境界層としての特徵 や，上昇流・下降流にとあなう凹凸が存在するかどうか を, 地震波解析によって調べればよい. 80 年代には大規 模マントル不均質の研究之並行して, これらの比較的微 細な構造についての知見も数多く得られた.

\section{1 熱境界層の推定}

マントル対流のセルの形状を知る手がかりとして, 水 平方向不均質の強さの深さ分布を調べるという方法があ る [HoNDA (1987)]. 熱対流のセルの最上部・最下部は 熱境界層になり熱伝導が温度分布を支配するため, 対流 セル内部よりも水平方向不均質の度合は強くなる。 した がって, 地表や $\mathrm{CMB}$ 付近では水平方向不均質が強く なっていることが予想される. また，上部・下部マント ルで対流が別々のセルを成しているとすれば，深さ 650 $\mathrm{km}$ 付近であ水平方向不均質が強くなるだろう.

実際, 80 年代前半までに提出された長周期表面波か ら推定した上部マントル不均質モデル [WoodHouse and DzIEWONSKI (1984), NATAF et al. (1986)] と短周期 $\mathrm{P}$ 波から推定された下部マントル不均質モデル [CLAYT- on and Comer (1983), Dziewonski (1984), Inoue et al. (1990)] によれば， 上部マントルの最上部と下部マント ル最下部で水平方向不均質のパワーが強くなっているこ とが分かり，マントル最上部・最下部が対流セルの最上 部・最下部になっているという考えを支持している。し かし，深さ $650 \mathrm{~km}$ でそれがどうなっているかについて は意見が分かれている.この原因の一つとして, 上部、 ントルを推定したときに用いた長周期表面波, 下部マン トルで用いた短周期 $\mathrm{P}$ 波が両方とも $650 \mathrm{~km}$ 付近の速 度不均質に対する分解能や精度に乏しいことがある. 80 年代後半になって長周期表面波・長周期実体波を用いて 上部・下部マントルの不均質を同時に推定した研究 [DzIEWonski and Woodhouse (1987), TANimoto (1987, 1990)]が始まるにいたり，この問題について従来より精 度のよい議論ができるようになったが，まだ最終的な決 着はついていない. 本多 (1988b) は, TANI-MOTO (1987) が求めた深さ $1,000 \mathrm{~km}$ までの $\mathrm{S}$ 波速度不均質モデルか ら水平方向不均質の強さの深さ分布を計算し, $650 \mathrm{~km}$ 付近に不均質パワーのピークがあることを示し， 650 $\mathrm{km}$ 不連続面が熱境界層になっていることを示唆してい る. Woodhouse and DzIEwonski (1987) む650 km 付 近で水平方向不均質が強くなっていることを指摘し, 本 多の示唆を支持する結論を出した。 しかし, 最近 TANIмото (1990) がデータを增やし全マントルの S 波速度不 均質モデルを推定した結果では, 深さ $650 \mathrm{~km}$ に不均質 パワーのピークはみられない. また INOUE et al. (1990) の全マントルP 波速度不均質モデルであ, 深さ $650 \mathrm{~km}$ 付近に不均質パワーの強いピークはみられない。 


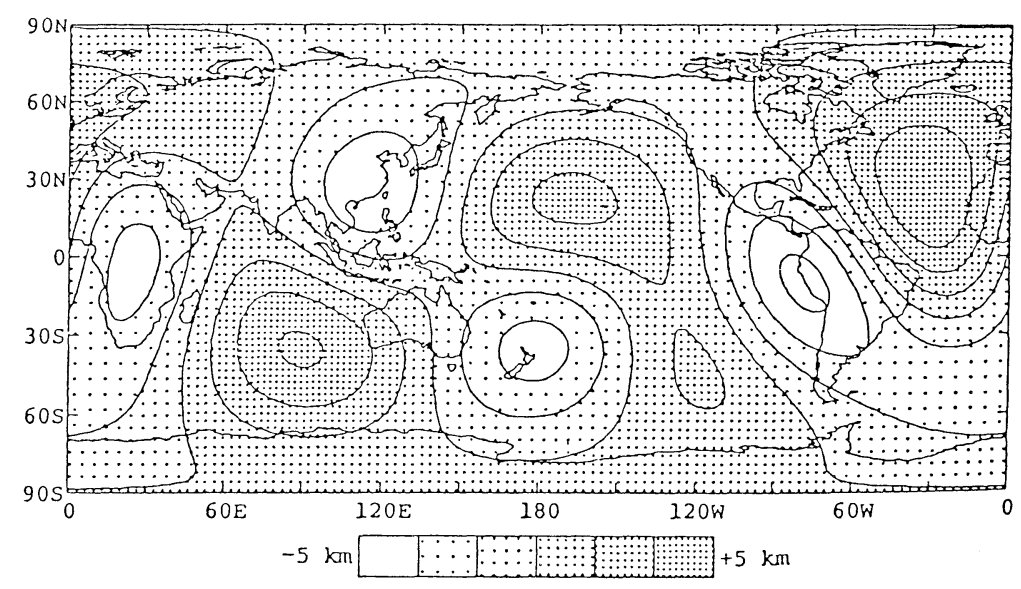

Fig. 8. Topography of CMB obtained by inversion of the combined PcP and PKP data set. Spherical harmonic expansion is limited to degree and order 4. After Morelli and Dziewonski (1987).

\section{2 最下部マントル}

マントル対流が存在すればそれにともなって CMBに 凹凸地形が生じるはずである，凹凸地形は実体波走時に 影響を及ぼすが，それをデー夕から取り出すためにはマ ントル不均質の影響を補正しなければならない. そのた め, 実際に地震学的に地形図を作るという試みが始まっ たのは, マントル 3 次元速度構造モデルが得られるよう になったここ 5 年のことである. MoRELli and DzIEWONSKI (1987) は, PCP 波と $\mathrm{PKP}_{\mathrm{BC}}$ 波の走時デー夕を用 いて次数 4 までのコアーマントル境界面の凹凸を推定 した. PcPだけあるいは $\mathrm{PKP}_{\mathrm{BC}}$ だけを用いたのでは, 走 時に対する凹凹の影響とマントル最下部及びコア最上部 の速度不均質の影響とを分離できないが, 両方の相の走 時を用いれば凹凸の影響だけを取り出してマッピングす ることができる. 彼らの結果で興味深いのは, 凹（下向 きのへこみ）の地域が環太平洋の沈み込み帯に一致し,

凸（上向きの盛り上がり）の地域が太平洋中心部に対応 することである (Fig. 8). 環太平洋は下部マントルの高 速度帯に対応し, 太平洋中心部は低速度域に対応してい るからここの凹地形はスラブの沈み込みに関係した下部 マントルの下降流に, 凸地形は上帠流によるのかもしれ ない.しかし彼らの推定した CMB の地形は, HAGER and Clayton (1989) (第 3 章) がジオイド計算にとも なって理論的に求めた CMB の地形と振幅・パターン共 にまったく合わない.この理由としてまず考えられるの は, 地震学的に求めた CMB 地形がまだ十分に正確では ないという可能性である. CREAGER and JORDAN (1986 a) は $\mathrm{PKP}_{\mathrm{AB}}$ と $\mathrm{PKP}_{\mathrm{BC}}$ とから $\mathrm{CMB}$ の地形を推定してい るが, MORELLI and DzIEWONSKI (1987) と全く異なるパ ターンを得ている. MoRelli and DzIEWONSKI (1987) む
CREAGER and JoRdAN (1986a) む ISC 走時データを用い て大きな䛊差を含むデータの中から凹凸による弱いシグ ナルを取り出そうとしているので, デー夕誤差が両者の 結果の違いを引き起こし，さらにはジオイドからの予測 との食い違いの原因となっているのかもしれない。しか し, ジオイドとの食い違いの原因が Hager らのジオイ ド計算の方にあるという可能性あある. Hager らは化学 的境界面として $650 \mathrm{~km}$ 不連続面のみを考慮したが, 、 ントル内部に別の化学的境界面があるとすると凹凸のパ ターンは大きく変わり得るからだ. 現在具体的に考えら れている化学的に異質な層として, 最下部マントル ( $\mathrm{D}^{\prime \prime}$ 層) がある.

最近, Lay らのグループは実体波波形解析に基づい て, $\mathrm{D}^{\prime \prime}$ 層の上に速度不連続面があり, しかもその不連 続面の深さが水平方向に大きく変化しているということ を主張している. Lay らは, Fig. 9 で示した地域の最下 部マントルを通る $\mathrm{S}$ 波と $\mathrm{ScS}$ 波の間に明瞭な相を見い 出し，それを CMB の上 $200 \sim 300 \mathrm{~km}$ の深さに速度が $3 \%$ 増加する不連続面からの反射波であると解釈した [YounG and LAY (1987) のレビュー参照].これは, 最 下部マントルを単なる熱境界層であると考えては解釈で きない，熱境界層であるとともに，コアとマントルとい う化学的に異なる構成物質の間の化学的境界層であある ということを意味しているのかも知れない [YounG and LAY (1987)]. また, 太平洋を取り囲む地域では不連続面 がみられるが太平洋の直下には不連続面はない [GARNERO et al. (1988)] という解析結果から, この不連続面 は沈み込んだスラブと関係しているのかもしれないとい う議論ああり [LAY (1989)], 不連続面の解釈はまだ固 まっていない. それ以前に, 不連続面の存在そのものを 

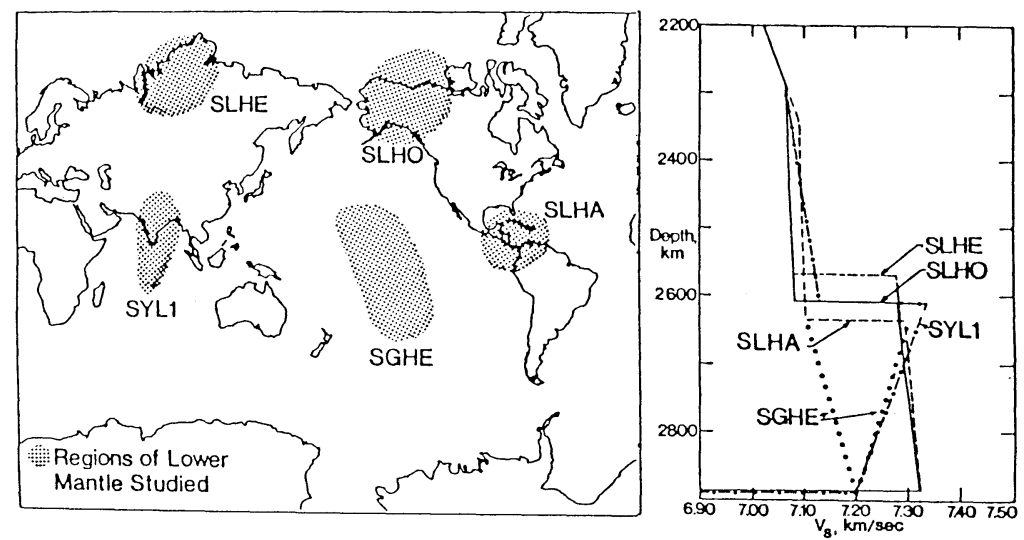

Fig. 9. S velocity models with discontinuities at the top of the D" layer, which are obtained for various localized regions of D" (hatched regions in the left figure). The model SGHE involves strong lateral gradients in S velocity in the region below the central Pacific. After LAY (1989).

否定する研究者も多い，Lay らの見いだした相は $\mathrm{D}^{\prime \prime}$ 相 内の水平方向不均質による散乱として解釈でき, 不連続 面は必要ないという反論 [HADDON and BUCHBINDER (1987)] や回折 P, S 波や多重反射 ScS 波の解析から不連 続面の存在を否定する結果も出されている [SCHLITTENHARTDT et al. (1985), REVENAUGH and JoRDAN (1989)]. $\mathrm{D}^{\prime \prime}$ 層の性質は現在最む大きく意見の分かれているとこ ろである.

\section{$4.3650 \mathrm{~km}$ 不連続面}

上部・下部マントル境界面 ( $「 650 \mathrm{~km}$ 不連続面」と呼 ぶが, 必ずしもちょうど深さ $650 \mathrm{~km}$ に不連続面がある という意味ではないことに注意）が単なるポストスピネ ル相転移境界か, それとも相転移に加えて化学的組成の 境界面でもあるのかどうかについては多くの議論がなさ れている [例えば LEEs et al. (1983)]. 化学的境界面は上 部・下部マントルに分かれた二層対流を示唆するから， $650 \mathrm{~km}$ 不連続面の性質を地震学的に知ることはマント ル対流のパターンを明らかにするためにあ必要なことで ある. $650 \mathrm{~km}$ 不連続面の性質を知るために現在用いら れている最あ分解能の高い方法は, 不連続面での実体波 反射・変換波を解析することである. 80 年代以前の地 震学的アプローチは， $\mathrm{P}^{\prime} 650 \mathrm{P}^{\prime}$ (震源から出た $\mathrm{P}$ 波が地 球の裏側の $650 \mathrm{~km}$ 不連続面で反射して戻ってきた波) の走時や振幅から $650 \mathrm{~km}$ 不連続面の実際の深さや速 度不連続のシャープさの程度を推定する方法が多く [例 えば ENGDAHL and FLINN (1969), RICHARDS (1972)], また調べられた $650 \mathrm{~km}$ 不連続面は主に南極付近やイ ンド洋など限られた地域でしかなかった。

80 年代の研究の特徴は, $\mathrm{P}^{\prime} 650 \mathrm{P}^{\prime}$ [NAKANISHI (1988 b)] に加えて, 震源や観測点付近直下の $650 \mathrm{~km}$ 不連続 面での SP 変換波 [BARLEY et al. (1982), Bock and $\mathrm{HA}_{\mathrm{A}}$
(1984), RICHARDS and WICKS (1990)] やPS变換波 [PAULSSEN $(1985,1988)]$ を用いた研究が盛んに行なわ れるようになり, 調查地域がヨーロッパ大陸, 北米大陸, 沈み込み帯, 海嶺などに広がったことである. また最近, REVENAUGH and JoRdAN $(1987,1989)$ は地表面と CMB で多重反射する $\mathrm{ScSn}$ 波の波形から, 震源と観測点の間 の $650 \mathrm{~km}$ 不連続面の平均的性質を推定するという新 しいアプローチを西太平洋に適用した。この研究は $\mathrm{P}^{\prime}$ $650 \mathrm{P}^{\prime}$ や变換波を用いた研究が不連続面の性質を地球上 で点的に推定したのに対して, 震源と観測点を結ぶ線的 な推定を行なったという点で大きな意味がある。

これまでの地震学的研究の結果として分かってきたこ との一つは， $650 \mathrm{~km}$ 不連続面は非常にシャープ $(5 \mathrm{~km}$ 程度）であることである。これに対して物質科学の立場 から二つの異なった解釈がなされている. LeEs et al. (1983) はポストスピネル相転移がどの程度の圧力範囲 (すなわち深さ範囲) で起きるかを高圧実験によって求 めた。 その結果, 地震波から推定される大きな反射係数 （約 10\%）は相転移境界だけでは説明できず， $650 \mathrm{~km}$ 不連続面は化学組成の変化をともなっていると主張し た. しかし最近 ITO and TAKAHASHI (1989) は, より良 く圧力・温度をコントロールした実験の結果, ポストス ピネル相転移は非常に狭い圧力範囲 (深さ範囲で $5 \mathrm{~km}$ 程度) で起こり, LEEs et al. (1983) の結論と逆に相転移 のみで地震波の大きな反射係数を十分説明できるという 結果を出している.

むう一つの地震学的研究の結果は, 不連続面に水平方 向の波長が数 $100 \sim 5,000 \mathrm{~km}$, 起伏 $20 \mathrm{~km}$ 程度の凹凸 があり, また不連続のシャープさす水平方向に变化して いるということである. REVENAUGH and JORDAN (1989) は ScSn の波形解析から, 西太平洋において沈み 


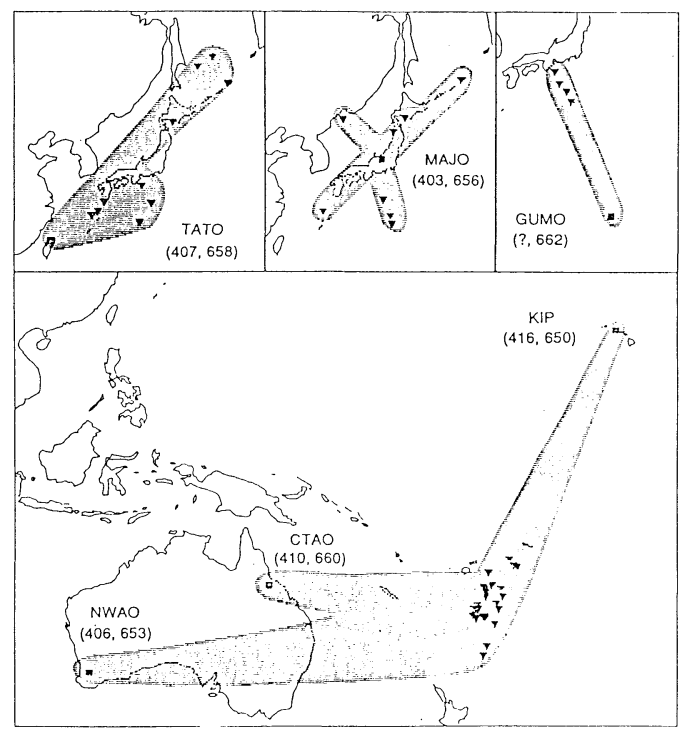

Fig. 10. The maps of the western Pacific showing the portions of the transition zone sampled by the six seismic corridor of multiple ScS waves (shaded regions). The pathaveraged depths of the $400-\mathrm{km}$ and $650-\mathrm{km}$ discontinuities are indicated in the brackets for each seismic corridor. After Revenaugh and JORDAN (1989).

込み帯での $650 \mathrm{~km}$ 不連続面が海洋地域での不連続面 と比べて平均的に 5〜 $10 \mathrm{~km}$ 深いところにあるという 興味深い結果を出した (Fig. 10).この凹凸のセンスはポ ストスピネル相転移曲線 [例えば，ITO and YAMADA (1982)］に基づく推定に合う。このことから彼らは不連 続面の凹凸が相転移によって生じているのではないかと 主張している，さらに， $650 \mathrm{~km}$ 不連続面が化学的不連 続だとすると凹凸の振幅は 50〜 200 km 程度になるはず だが [例えば, Christensen and Yuen (1984)]，そのよ うな大きな凹凸は観測されないので $650 \mathrm{~km}$ 不連続は 単なる相転移面であろうと議論している。 NAKANISHI (1988b) は大西洋中央海嶺付近の $650 \mathrm{~km}$ 不連続面から の $\mathrm{P}^{\prime} 650 \mathrm{P}^{\prime}$ の振幅を調べ, 反射点が海嶺軸に近づくほど 反射係数が小さくなることを見いだした．これは，海嶺 直下で不連続面の性質が変化していることを示している のかもしれない.

$650 \mathrm{~km}$ 不連続面の性質の水平方向の变化加ら不連続 面の成因や対流パターンを議論するには，現在はまだ調 查された地域が少なすぎる. 80 年代の地震学は $650 \mathrm{~km}$ 不連続面の水平方向変化に対するそれまでの点的理解 を, 線的理解へと進めた. Revenaugh and Jordan の方 法をもっと多くの地域に適用すれば，面的に不連続面の
不均質構造を明らかにすることができるかもしれない。

\section{§5. スラブ・ペネトレーション}

スラブが下部マントル内まで沈み込んでいる（スラ ブ・ペネトレーション) かどうかという問題は, マント ル対流のセルが上部・下部マントルで分かれているか㔻 かに関わる重要な問題である. スラブ・ペネトレーショ ンが直ちに全マントル対流を意味するわけではないが, かなりの上部マントル物質が下部マントル内に漏れ出て いるということを意味するので，少なくとも上部・下部 マントルに完全に分離した二層マントル対流モデルは考 えにくくなるだろう.

全世界的に沈み込み帯の地震活動の深さによる变化を 見ると, 深さ $100 \mathrm{~km}$ 以浅で地震の数が最大になりそこ から深さ $400 \mathrm{~km}$ までは減少傾向になるが, 深さ500〜 $600 \mathrm{~km}$ で再び地震活動が増大する傾向があり, 深さ $700 \mathrm{~km}$ を越えると地震活動はパタリと止んでしまう [例えば RICHTER (1979)]. また深さ 500〜600 km の地 震のメカニズムを調べると，スラブ沈み込みの方向に圧 縮応力が働いていることが分かる [例えば IsACKs and MOLNAR (1971)]. そのため, 70 年代までは $650 \mathrm{~km}$ 不 連続面はスラブ沈み込みに対するバリアになっており, スラブ・ペネトレーションは起こり得ないとする考えが 主流だった [例えば, RICHTER (1979)]. しかし, 上部マ ントルでは，地震を起こさずに沈み込んでいるスラブの 存在が示唆されている例があり［例えば, MCKENZIE and Julian (1971), NAKANishi (1980), ENGDAHL and GuBBINS (1987)], 地震活動がスラブの存在を示す絶対 的な指標であるとは言えない，また，下部マントルの粘 性が上部マントルよりも 10 倍以上高ければスラブ・ペ ネトレーションがあってもスラブ深部では沈み込み方向 に圧縮応力が生じることが理論計算によって示されてい る [VASSILIOU and HAGER (1988)]. 従って, スラブ・ペ ネトレーションを議論するためのもっとも重要な手がか りは，スラブの沈み込みにともなう地震波高速度帯が沈 み込み帯下部マントルにあるか否かを地震波解析から調 ベることであろう.

80 年代になって, 沈み込むスラブが下部マントル内 まで地震を伴わずに沈み込んでいるという仮説が賛否両 論を大きく巻き起こした. スラブ・ペネトレーションを 地震波解析に基づいて最初に主張したのは JORDAN (1977) であるが, CREAGER and JoRdAN (1984, 1986b) が北西太平洋のクリル・カムチャッカ弧, 東北日本弧, マリアナ弧の沈み込み带でのスラブ・ペネトレーション を検出したと主張して大きな反響を呼んだ. その後, 様々なデータや解析手法で Jordan らの結果を検証し, 

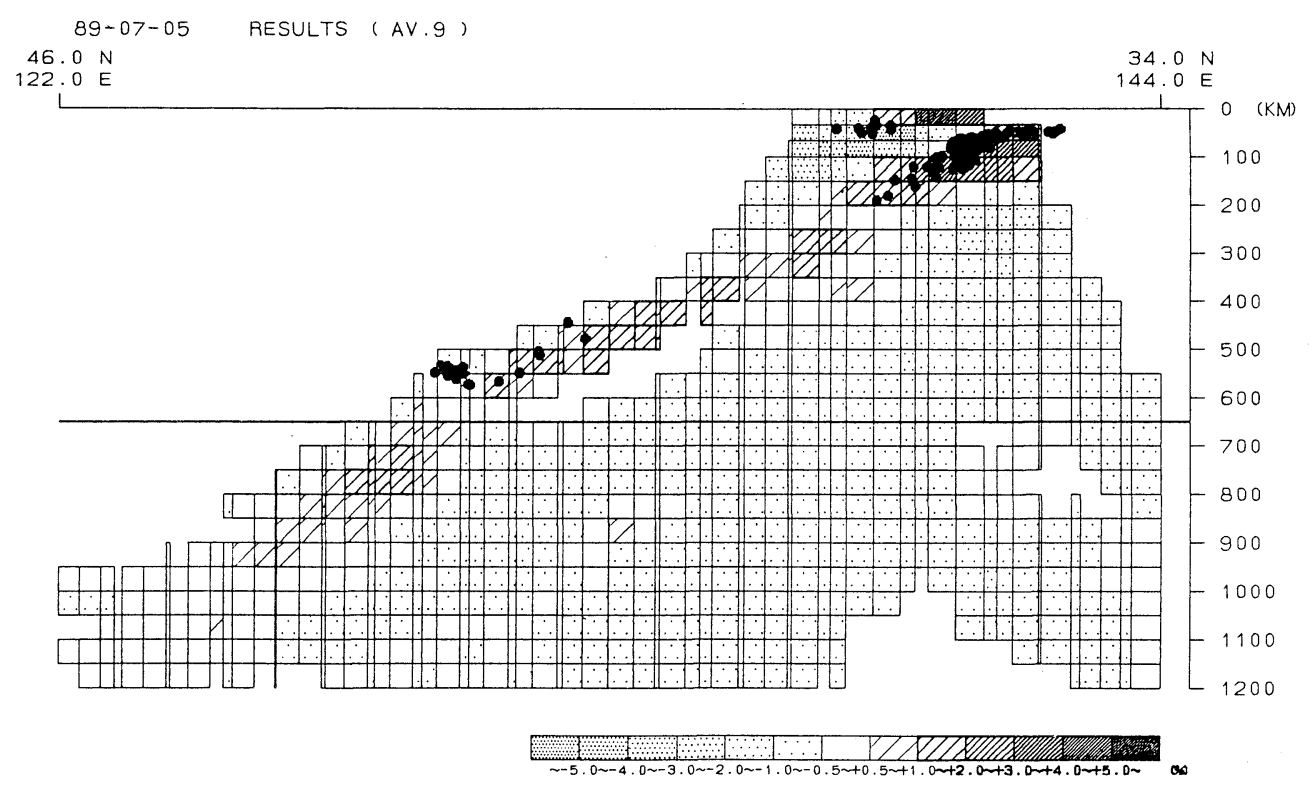

Fig. 11. P wave velocity structure beneath the central Japan obtained by a tomographic inversion. Cross section taken perpendicular to the Japan trench is shown. Solid circles indicate hypocenters of the events used for the inversion. Note that a high-velocity anomaly continuing from the Japan trench down to a depth of $1,000 \mathrm{~km}$. After Miyatake and Hirahara (1989).

あるいは彼らが扱っていない沈み込み帯でのスラブ・ペ ネトレーションを調べる研究が相次いだ（1987 年まで の研究については末次 (1987) に詳しい) が, まだ決着が 付いたと言うにはほど遠い。ほとんどの沈み込み帯でス ラブ・ペネトレーションがあるという JORDAN et al. (1989) の主張むあれば, 逆にほとんどの沈み込み帯でス ラブは下部マントルに沈み込んでいないというZHOU and CLAYTON (1990) らの反論むある. 同様のデー夕, 同様の手法を用いているのにも関わらず異なる結果がで るといった例すらあるのが現状だ。この混乱の原因とし て特に初期の研究に於て，(1)用いたデー夕（主に ISC 走時デー夕）の質がスラブ・ペネトレーションという比 較的微細な構造の問題を扱うには悪く, 手法の微妙な違 いによって結果が大きく左右された；(2) 全マントルを 伝搬してきた実体波からスラブ・ペネトレーションにつ いての情報を抽出するためには地球の他の領域の不均質 性について注意深い補正をする必要があるが，この点に 対する配慮が少なかった, 等の問題をあげることができ る. 最近の研究では上述の問題点を完全には克服できて いないまであ，より慎重に留意するようになってきてい る. それらの研究によれば, スラブは全地球的に下部マ ントルに沈み込んでいるのではなく, スラブ・ペネト レーションが起きているか否かは沈み込み帯によって異 なるようである.

深発地震の $\mathrm{P}$ 波走時データを用いた研究によれば, ク
リル弧 [Zhou and Clayton (1990), Suetsugu (1989), 宮武・平原 (1989)], 東北日本弧 (Fig. 11) [KAMIY A et al. (1988), TAKEI and Suetsugu (1989), 宮武・平原 (1989)] でスラブ・ペネトレーションに伴うと思われる 高速度帯があるという結論が大勢を占めている（但し東 北日本弧については ZHOU and CLAYTON (1990) はP 波 走時解析によって逆にスラブが $650 \mathrm{~km}$ 不連続面の上 に横たわっていると結論している). クリル弧について は特に詳しく調べられており, 走時デー夕の他に樑発地 震のP 波振幅 [SUETSUGU (1989)] や S 波波形 [SILVER and Chan (1986), BeCK and LAy (1986), Cormier (1989)] デー夕を解析してスラブ・ペネトレーションの 存在を主張する研究がある（むっとあ後述のように, 振 幅や波形デー夕を用いた研究は走時デー夕による研究以 上に研究者間の食い違いが大きい)，GRAND (1987) は精 密に測定した S と SS 波走時デー夕を用いて, 北米大陸 東部からカリブ海にかけての下部マントル深さ 1,200〜 $1,600 \mathrm{~km}$ に鉛直状の高速度帯があることを示し, 続い て VIDALE and GARCIA-GonZALEZ (1988) も S 波の波形 解析によってその存在を確認した. GRAND (1987) はこ の高速度帯を 40〜100 Maに北米に沈み込んでいた ファラロン・プレートだと推論している. またINOUE $e t$ al. (1990) は大量の $\mathrm{P}$ 波走時データを用いて全マントル 不均質モデルを求め, 上述の島弧の他に, ジャワ弧・卜 ンガ弧・ペルー・チリ弧です下部マントルに高速度帯が 


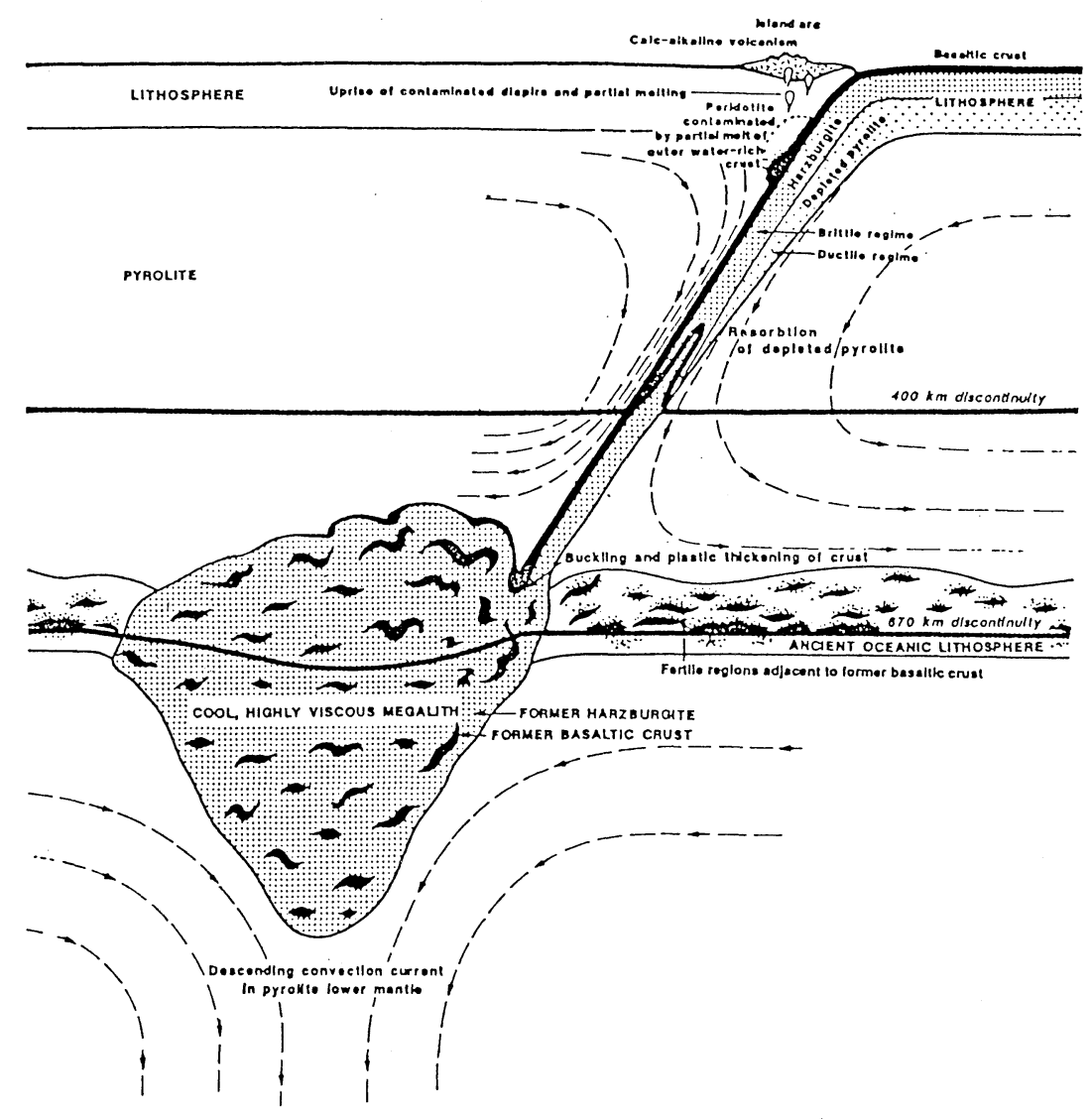

Fig. 12. Model showing subduction of a cool, thick plate of differentiated oceanic lithosphere. The tip of the plate experiences buoyant resistance when it penetrates into the lower mantle. Below $670 \mathrm{~km}$ discontinuity, the former oceanic crust and harzburgite layers may plastically thicken and buckle to form a megalith. The megalith is a transient feature and ultimately becomes entrained in the convective regime of the lower mantle. After Ringwood and Irifune (1988).

あると指摘している.

逆にスラブ・ペネトレーションが起きていないことが はっきりしてきた島弧むある. ENGDAHL and GubBINS (1987) は中央アリューシャン弧の沈み込み帯速度構造 を推定し, スラブの深度が $400 \mathrm{~km}$ 程度であることを示 した．伊豆・小笠原弧でスラブが $650 \mathrm{~km}$ 不連続面上に 横たわっていることが走時解析を通じて報告されている [Zhou and Clayton (1990), Okino et al.(1989)] ほか, マリアナ弧であ CREAGER and JORDAN (1986b) の結論に 反してスラブが下部マントル内まで沈み込んでいないこ とが走時解析によって示唆されている[岡野・末次 (1989)].

以上述べたように, 研究者による結果の食い違いは 残っているが, スラブ・ペネトレーションが起きている 島弧, 起きていない島弧があることは確かなようだ。こ れは, 少なくとも $650 \mathrm{~km}$ 不連続面の一部を通して物質
の流れが存在することを意味し, 二層対流モデルが地震 学からの結果と矛盾することを示唆している. しかし, スラブ・ペネトレーションが起きていない島弧も少なか らず存在するということは, 単純な全マントル対流モデ ルにも疑問を投げかける。 それでは, スラブ・ペネト レーションの地域性を生んでいる原因は何なのだろう か?

スラブ・ペネトレーション（の存否）に地域性がある ことは, RINGWOOD and IRIFUNE (1986) が岩石の高圧実 験の結果に基づいて予想している. $650 \mathrm{~km}$ 不連続面で はマントル物質の高圧相転移の結果スラブに浮力が働 き，下部マントルに沈み込みにくくなる．そのため年代 の若いスラブは $650 \mathrm{~km}$ 不連続面上に横たわるが, 古い スラブは低温による負の浮力が相転移の浮力に打ち勝ち $650 \mathrm{~km}$ 不連続面を突破するという説である.この説 は，アリューシャン弧で若いスラブが下部マントルまで 
沈み込んでいないことや，クリル・東北日本弧で古いス ラブが下部マントルに沈み込んでいるという地震学的な 結果を説明することができる. しかし，最も古いスラブ が沈み込んでいる伊豆・小笠原・マリアナ弧でスラブ・ ペネトレーションがないという地震学からの結果を説明 することは困難なように思える。この問題を解決するた めに，伊藤・佐藤 (1990) は上部マントル・スラブ内部 でのオリビン $\beta$ スピネル相転移の速度論的効果 [SUNG and BURNS (1976)] を考慮している. むしスラブの温度 が十分低く，オリビン $\beta$ スピネル相転移の反応速度がス ラブ内部で非常に遅いとすると, スラブ内部の相転移面 は周用のマントルでの相転移面（約 $400 \mathrm{~km}$ ）よりも深 部に位置するだろう。このスラブ内外の相転移面のずれ はスラブに正の浮力を及ぼし，スラブを沈み込み難くす る. 正の浮力（=スラブ沈み込みへの抵抗力） はスラブ が冷たい（古い）ほど大きくなるので，伊豆・小笠原・ マリアナ弧に沈み込む古いスラブは下部マントルに沈み 込み難いことになり, 地震学からみたスラブ・ペネト レーションの地域性をうまく説明できる.これが正しい とするとスラブ内部で深さ 400～600 km の間に準安定 状態のオリビン（ $\beta$ スピネルよりあ地震波速度は低い） が存在するはずである.この説を更に検証するために, この深さでスラブ内部速度構造を調べて準安定状態の才 リビンの存在を確かめる必要があろう.

これまで主に走時解析の結果を紹介し，議論をスラ ブ・ペネトレーションの有無に絞り, 下部マントル・ス ラブの形状（厚さ，長さ）には触れなかった。実際, FISCHER et al. (1988) が示したように，走時デー夕には 下部マントル・スラブの厚さや長さを正確に推定するだ けの分解能はない。一方理論計算から，実体波波形や振 幅がスラブの形状に強い影響を受けることが分かってい る [Vidale (1987), Engdahl et al. (1988), Suetsugu (1989), WEBER (1990)]. 従って，実体波振幅や波形デー 夕を解析すれば, 走時デー夕と独立なデー夕としてスラ ブ・ペネトレーションの正否を検証できるのみならず, スラブの形状まで議論することができ, スラブの辿る運 命に対して強い制約を与えることができるはずである. 例えば，RINGWOOD and IRIFUNE (1986)の説では古いス ラブが下部マントル内に達する際に，スピネルーポスト スピネル相転移による強い浮力のためにバックリングを 起こしメガリスを形成する (Fig. 12) が，メガリスのよ うな形状は実体波の走時だけでなく振幅・波形を調べて 初めて捉えることができる。しかし，振幅・波形解析の 結果は現在のところ研究者間で大きく矛盾している. ENGDAHL et al. (1988) ट CORMIER (1989) は, 波形解析 からクリル弧のスラブは下部マントルに入って厚さを増
していることを示唆している。逆に SILVER and CHAN (1986) はクリル弧のスラブは下部マントル内に厚さを 変えることなく沈み込んでいるモデルを提案した。 また Suetsugu (1989) はクリル弧の深発地震の遠地短周期 P 波振幅データと様々な下部マントル・スラブモデルから 計算される理論振幅とを比較し, 下部マントル・スラブ の厚さは上部マントル・スラブとほとんど変わらないと 主張した。このほか, LAY and Young (1989) は波形解 析を, WEBER (1990) は振幅解析を行ない, 明瞭にスラ ブによると言えるような波形・振幅異常はみられないと 主張している．現在の食い違いの原因は，振幅や波形か ら精度のよい構造解析をするだけの良質なデータがまだ 不足しているというところにあると思われる。振幅や波 形データを活用してスラブ・ペネトレーションやスラブ の形状を推定するという研究はまだ始まったばかりだ が，スラブ沈み込み様式の地域性を正確に知るために今 後重要になる。 そのためにも広帯域・高ダイナミックレ ンジのディジタル地震観測網の発達が必要である.

これまで，上部マントル・スラブから連続して下部マ ントルに傾き下がる高速度帯を暗に下部マントルに沈み 込むスラブだと解釈して話をすすめてきたが，この解釈 には異論がある. 本多 (1988b) は, 上部・下部マントル が別の対流セルを成しかつ両者の間に強い熱的カップリ ングが存在していれば，スラブ・ペネトレーションが起 きていなくても下部マントルに高速度帯が生じることを 対流の数值シミュレーションによって示した. スラブ・ ペネトレーションがこのような見かけのあのであるか否 かを知る一つの方法は, 上部マントル・スラブと下部マ ントル高速度帯の間によ゙の程度形状や内部構造の連続性 があるかを調べることである。 あう一つ考えられる方法 は $650 \mathrm{~km}$ 不連続面付近の地震波異方性を調べること である. 本多の考えているような熱的カップリングが上 部・下部マントルの対流に働いているとすれば $650 \mathrm{~km}$ 不連続面をはさんで対流は逆方向に流れていることにな る.そのため $650 \mathrm{~km}$ 不連続面付近は強いズリ変形の場 となり，それによって引き起こされた地震波異方性を観 測することによって，熱的にカップリングした二層対流 という仮説が正しいかどうか検証できるかもしれない [唐戸 (1986)]

\section{§6. まと め}

ここで紹介した研究の多くは, 地震波データのノイズ レベルぎりぎりのところで行なわれているため，提出さ れているモデル相互の矛盾はまだ大きい。これまでのモ デルはまだ Preliminary なものだと考えるべきである. 今後さらにマントル・ダイナミクスのイメージを地震学 
的な方法で明瞭なものにするためには，より広い帯域, より高いダイナミック・レンジ，より高い配置密度の地 震観測網が必要である。 また, 観測面の向上にともなっ てこれまで大部分の研究が頼ってきた地震波の走時デー 夕に加えて, 質のよい振幅や波形データを生かした高分 解能の地震波解析法も必要になろう.

80 年代の地震学の大きな特徵は, マントル対流の存 在や対流パターンを推定するのに必要な様々な地震学的 構造（例えば地震波速度異方性や不均質）を三次元的に 捉えることに具体的に手をつけ始めたところにある. 実 際に地震波速度不均質モデルから対流パターンを推定す る研究も現われてきた. しかしそれらの研究のほとんど は, 地球内部不均質構造の一部に注目して（即ち他の大 部分を軽視して）マントル全体の対流パターンを推定し ており [例えばJoRDAN et al. (1989)]，本論文で述べた ような様々な不均質パターンを統一的に説明しようとい う試みはまだまだこれからである。

序章で触れた全マントル対流モデルと二層対流モデル をめぐる論争に関連して本論文で紹介した研究結果を見 渡してみると, (1) マントル三次元大規模速度不均質構 造モデルでは, 遷移層から最下部マントルまで環太平洋 沈み込み帯に沿って高速度帯が延びている；(2)650 km 不連続面が化学的境界でない場合の方が, 三次元大規模 速度不均質モデルと観測されるジオイドパターンとが無 理なく調和する；(3) 地震学的に求めた $650 \mathrm{~km}$ 不連続 面のシャープさや起伏は, この面が単なる相境界である という考えと調和的である；(4) スラブの内の少なくと も一部は下部マントル内部まで沈み込んでいる, などは 全マントル対流を示唆する材料である. しかし他方で,

(1) マントル三次元大規模不均質モデルに於て, 低速度 域の位置は上・下部マントルで大きく異なっている; (2) スラブの一部は下部マントルまで沈み込んでいない, な ごは単純な全マントル対流では説明できない.

マントル対流の研究に地球科学の様々な分野からの総 合的なアプローチが必要不可欠であることは論を待たな い. そのような総合的研究も始められている. SILVER et al. (1988) は, マントル全体がプレートテクトニクスに 関与しているとは考えにくいという同位体地球化学加ら の要請とスラブが下部マントル内部まで沈み込んでいる という地震学的な結果を重視して, Penetrative Convection というモデルを提唱した。 このモデルでは 650 $\mathrm{km}$ 不連続面は化学的境界面であり，この面を挟んで下 部マントルは上部マントルよりも $2 \%$ 密度が大きい. 上 部マントルと下部マントルとの間の物質の行き来は，ス ラブとホットスポットの上昇流に限られる. スラブは下 部マントルに沈み込むが, 下部マントル内部で暖められ

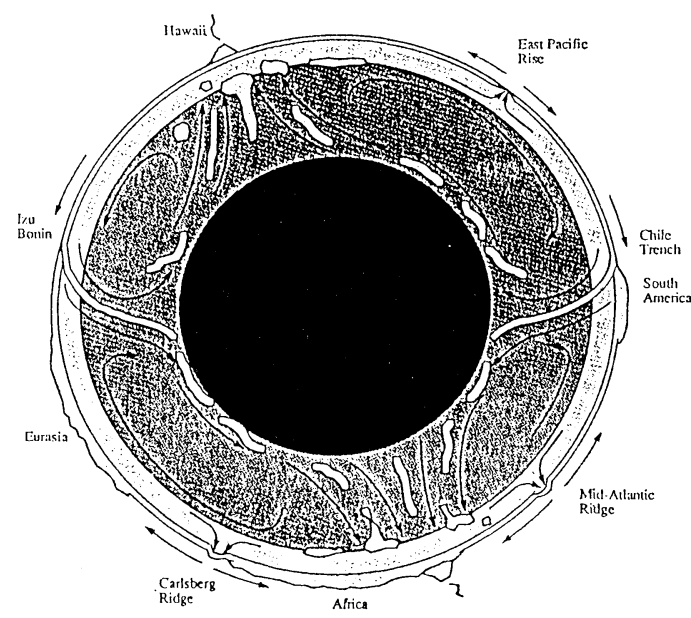

Fig. 13. Schematic drawing of penetrative convection in the Eaoth. Because of a $2 \%$ density increase form the upper to the lower mantle, slab material will descend into the lower mantle with little entrained flow and rapidly return to the upper mantle as a result of its intrinsic positive buoyancy while in the lower mantle. Slab represent the only flux through the transition zone, except perhaps for small amounts of entrained lower mantle material. After Silver et al. (1988).

て密度が周囲よりも小さくなるとスラブは上昇して再び 上部マントルに帰って来る (Fig. 13). この間スラブと下 部マントル物質の間に同化などの相互作用はほとんどな い.このモデルでは, 環太平洋沈み込み帯に沿った下部 マントル高速度帯の存在や, スラブ沈み込みの地域性, また上部・下部マントル低速度域がどの様に関係してい るのかなど答えるべき問題が残されており，仮説の域を 出ない. しかし, 地震学者と地球の物質科学や対流理論 など他分野との研究者との本格的な共同研究の先駆けと しての意義は大きい.

\section{文献}

AkI, K. and K. Kaminuma, 1963, Phase velocity of Love waves in Japan, 1, Love waves from the Aleutian shock of March 9, 1957, Bull., Earthq. Res. Inst. Tokyo Univ., 41, 243-259.

Barley, B. J., J. A. Hudson and A. Douglas, 1982, S to P scattering at the $650 \mathrm{~km}$ discontinuity, Geophys. J. Roy. Astr. Soc., 69, 159-172.

Beck, S. L. and T. LAy, 1986, Test of the lower mantle slab penetration hypothesis using broadbasnd $\mathrm{S}$ waves, Geophys. Res. Lett., 13, 1007-1010.

Bercovici, D., G. Schubert and G. A. Glatzmaier, 1989, Three-dimensional spherical models of con- 
vection in the Earth's mantle, Science, 244, 950955.

Bock, J. and J. HA, 1984, Short-period S-P conversion in the mantle at a depth near $700 \mathrm{~km}$, Geophys. J. Roy. Astr. Soc., 77, 593-615.

CAra, M. and J. J. LÉvêque, 1988, Anisotropy of the asthenosphere: the higher mode data of the Pacific revised, Geophys. Res. Lett., 15, 205-208.

Chapman, D. S. and H. N. Pollack, 1975, Global heat flow: a new look, Earth Planet. Sci. Lett., 28, 23-32.

Chase, C. G., 1979, Subduction, the geoid, and lower mantle convection, Nature, 282, 464-468.

Christensen, U. R. and D. A. Yuen, 1984, The influence of a subducting lithospheric slab with a chemical or phase boundary, J. Geophys. Res., 89, 43894402.

Clayton, R. W. and R. P. Comer, 1983, A tomographic analysis of mantle heterogeneities from body wave travel time data, EOS Treans. Am. Geophys. Uion, 64, 776.

Cormier, V.F., Slab diffraction of S waves, 1989, J. Geophys. Res., 94, 3006-3024.

Creager, K. C. and T. H. Jordan, 1984, Slab penetration into the lower mantle, J. Geophys. Res., 89, 3031-3049.

Creager, K. C. and T. H. Jordan, 1986a, Aspherical structure of the core-mantle boundary from PKP travel times, Geophys. Res. Lett., 13, 1497-1500.

Creager, K. C. and T. H. Jordan, 1986b, Slab penetration into the lower mantle beneath the Mariana and other island arcs of the northwest Pacific, J. Geophys. Res., 91, 3573-3589.

Dziewonski, A. M., 1984, Mapping the lower mantle: determination of lateral heterogeneity in $\mathrm{P}$ velocity up to degree and order 6, J. Geophys. Res., 89, 5929-5952.

Dziewonski, A. M. and J. H. Woodhouse, 1987, Global images of the earth's interior, Science, 236, 37-48.

Elsasser, W. M., P. Olson and B. D. Marsh, 1979, The depth of mantle convection, J. Geophys. Res., 84, 147-155.

Engdahl, E. R. and E. A. FlinN, 1969, Seismic waves reflected from discontinuities within earth's upper mantle, Science, 163, 177-179.

Engdahl, E. R. and D. Gubbins, 1987, Simultaneous travel time inversion for earthquake location and subduction zone structure in the central Aleutian Islands, J. Geophys. Res., 92, 13855-13862.

Engdahl, E. R., J. E. Vidale and V. F. Cormier, 1988, Wave propagation in subducted lithospheric slabs, in "Proceedings of the 6 th Course: Digital Seismology and Fine Modeling of the Lithosphere", International School of Applied Geophysics, Majorana Center, Erice, Sicily, Plenum Publishing Co.

Fischer, K. M., T. H. Jordan and K. C. CREAGER, 1988, Seismic constraints on the morphology of deep slabs, J. Geophys. Res., 93, 4773-4783.
Forsyth, D. W., 1975, The early structural evolution and anisotropy of the oceanic upper mantle, Geophys. J. Roy. Astr. Soc., 43, 103-192.

Garnero, E., D. Helmberger and G. Engen, 1988, Lateral variations near the core-mantle boundary, Geophys. Res. Lett., 15, 609-612.

Grand, S. P., 1987, Tomographic inversion for shear velocity beneath the North American plate, J. Geophys. Res., 92, 14065-14090.

Haddon., R. A. W. and G. G. R. Buchbinder, 1987, S-wave scattering by $3-D$ heterogeneities at the base of the mantle, Geophys. Res. Lett., 14, 891894.

HAGER, B. H., 1984, Subducted slabs and the geoid: constraints on mantle rheology and flow, J. Geophys. Res., 89, 6003-6015.

HAGer, B. H. and R. J. O'Connell, 1979, Kinematic models of large-scale flow in the Earth's mantle, J. Geophys. Res., 84, 1031-1048.

Hager, B. H., R. W. Clayton, M. A. Richards, R. P. Comer and A. M. Dziewonski, 1985, Lower mantle heterogeneity, dynamic topography and the geoid, Nature, 313, 541-545.

Hager, B. H. and R. W. Clayton, 1989, Constraints on the structure of mantle convection using seismic observations, flow models, and the geoid, in "Mantle convection, plate tectonics and global dynamics", ed. by W. R. Peltier, Gordon and Breach Science Publishers, New York, 657-764.

Hess, H. H., 1964, Seismic anisotropy of the uppermost mantle under oceans, Nature, 203, 629-631.

HondA, S., 1987, The RMS residual temperature in the conventing mantle and seismic heterogeneities, J. Phys. Earth, 35, 195-207.

本多了, 1988a, マントル対流論の現状, 地震 2,40 , $271-282$.

本多了, $1988 b$, 柔らかい境界面を持つ二層対流一ス ラブペネトレーションとマントル対流—, 地震 2,40 , 585-592.

Inoue, H., Y. Fukao, K. Tanabe and Y. Ogata, 1990, Whole mantle P-wave travel time tomography, Phys. Earth Planet. Interiors, 59, 294-328.

Isacks, B. and P. Molnar, 1971, Distribution of stresses in subducting lithosphere from a global survey of focal mechanism solutions of mantle earthquakes, Rev. Geophys. Space Phys., 9, 103174.

伊藤英司・佐藤博樹, 1990 , 相転移からみた沈み込むス ラブの詳細な構造, 地球惑星科学関連学会 1990 年合 同大会予稿集, 118 .

ITo, E. and H. YAMADA, 1982, Stability relations of silicate spinels, ilmenites, and perovskites, in "High-Pressure Research in Geophysics", ed. by S. Akimoto and M. H. Manghnani, Reidel, Dordrecht 405-419.

Iто, E. and E. TAкAнAshi, 1989, Postspinel transformations in the system $\mathrm{Mg}_{2} \mathrm{SiO}_{4}-\mathrm{Fe}_{2} \mathrm{SiO}_{4}$ and some 
geophysical implications, J. Geophys. Res., 94, 10637-10646.

JoRDAN, T. H. 1977, Lithospheric slab penetration into the lower mantle beneath the Sea of Okhotsk, J. Geophys., 43, 473-496.

Jordan, T. H., A. L. Lerner-Lam and K. C. CReager, 1989, Seismic imaging of boundary layers and deep mantle convection, in "Mantle convection, plate tectonics and global dynamics", ed. by W. R. Peltier, Gordon and Breach Science Publishers, New York, 97-201.

Kamiya, S., T. Miyatake and K. Hirahara, 1988, How deep can we see the high velocity anomalies beneath the Japan Islands?, Geophys. Res. Lett., 15, 828-831.

唐戸俊一郎，1986，地震波速度異方性のメカニズム，唐 戸俊一郎・鳥海光弘編「固体と地球のレオロジー」, 東 海大学出版会, 東京, 312-333.

Karato, S., 1989, Seismic anisotropy: mechanisms and tectonic implications, in "Rheology of Solids and of the Earth", ed. by S. Karato and M. Toriumi, Oxford University Press, Oxford, 393-422.

KAWASAKI, I., 1986, Azimuthally anisotropic model of the oceanic upper mantle, Phys. Earth Planet. Interiors, 43, 1-21.

川崎一郎，1988，地震波速度異方性からみた海洋プレー トと上部マントル低速度層, 火山, 33, 185-201.

KaWASAKI, I., 1989, Seismic anisotropy in the Earth, in "Encyclopedia of Solid Earth Geophysics", ed. by D. E. James, Van Nostrand Reinhold, Penn., 9941005.

KawASAKI, I. and F. Kon'no, 1984, Azimuthal anisotropy of surface waves and the possible type of the seismic anisotropy due to preferred orientation of olivine in the uppermost mantle beneath the Pacific ocean, J. Phys. Earth, 32, 229-244.

Kumazawa, M. and O.L. Anderson, 1969, Elastic moduli, pressure derivatives, and temperature derivatives of single crystal olivine and single crystal forsterite, J. Geophys. Res., 74, 5961-5972.

LAY, T., 1989, Structure of the core-mantle transition zone: a chemical and thermal boundary, EOS Trans. Am. Geophys. Union, 70, 49-59.

LAY, T. and C. J. Young, 1989, Waveform complexity in teleseismic broadband SH displacements: slab diffraction or deep mantle reflections?, Geophys. Res. Lett., 16, 605-608.

LEES, A. C., M. S. T. BuKowinski and R. JEANLOz, 1983, Reflection properties of phase transition and compositional change models of the $670-\mathrm{km}$ discontinuity, J. Geophys. Res., 88, 8145-8159.

Maupin, V., 1985, Partial derivatives of surface wave phase velocities for flat anisotropic models, Geophys. J. Roy. Astr. Soc., 83, 379-398.

McKenzie, D. and B. Julian, 1971, Puget Sound, Washington, earthquake and the mantle structure beneath the northwestern United States, Geol. Soc.
Am. Bull., 82, 3519-3524.

McKenzie, D. and N. Weiss, 1975, Speculations on the thermal and tectonic history of the Earth, Geophys. J. Roy. Astr. Soc., 42, 131-174.

宮武 隆・平原和郎, 1989, 日本列島下の三次元地震波 速度構造 (3), 地震学会講演予稿集, No. 1, 288.

Montagner, J. P., 1985, Seismic anisotropy of the Pacific Ocean inferred from long-period surface waves dispersion, Phys. Earth Planet. Interiors, 38, $28-50$.

Montagner, J.P. and H.C. Nataf, 1986, A simple method for inverting the azimuthal anisotropy of surface waves, J. Geophys. Res., 91, 511-520.

Montagner, J.P. and N. Jobert, 1988, Vectorial tomography-II. Application to the Indian ocean, Geophys. J., 94, 309-344.

Montagner, J.P. and H.C. Nataf, 1988, Vectorial tomography-I. Theory, Geophys. J., 94, 295-307.

Montagner, J. P. and T. Tanimoto, 1990, Global anisotropy in the upper mantle inferred from the regionalization of phase velocities, J. Geophys., Res., 95, 4797-4819.

Morelli, A. and A. M. Dziewonski, 1987, Topography of the core-mantle boundary and lateral homogeneity of the liquid core, Nature, 325, 678-683.

NaKanishi, I., 1980, Precursors to ScS phases and dipping interface in the upper mantle beneath southwestern Japan, Tectonophysics, 69, 1-35.

中西一郎, 1988a, 地球内部構造に関連する最近の地震 学的研究, 地震 $2,41,133-144$.

NAKANISHI, I., 1988b, Reflections of $\mathrm{P}^{\prime} \mathrm{P}^{\prime}$ from upper mantle discontinuities beneath the Mid-Atlantic Ridge, Geophys. J., 93, 335-346.

NaKanishi, I. and D. L. Anderson, 1984, Aspherical heterogeneity of the mantle from phase velocities of mantle waves, Nature, 307, 117-121.

Nataf, H. C., I. Nakanishi and D. L. Anderson, 1986, Measurements of mantle wave velocities and inversion for lateral heterogeneities and anisotropy 3. Inversion, J. Geophys. Res., 91, 7261-7307.

Nicoras, A., J. L. Bouchez, F. Boudier and J. C. MerCIER, 1971, Textures, strucrtures and fabrics due to solid state flow in some European Lherzolites, Tectonophysics, 12, 55-86.

Nishimura, C. E. and D. W. Forsyth, 1985, Anomalous Love-wave phase velocities in the Pacific: Sequential pure-path and spherical harmonic inversion, Geophys. J. Roy. Astr. Soc., 81, 389-407.

Nishimura, C. E. and D. W. Forsyth, 1988, Rayleigh wave phase velocities in the Pacific with implications for azimuthal anisotropy and lateral heterogeneities, Geophys. J. Roy. Astr. Soc., 94, 479-501.

Nishimura, C.E. and D. W. Forsyth, 1989, The anisotropic structure of the upper mantle in the Pacific, Geophys. J., 96, 203-229.

ОкаL, Е. А., 1977, The effect of intrinsic oceanic upper-mantle heterogeneity on regionalization of 
long-period Rayleigh-wave phase velocities, Geophys. J. Roy. Astr. Soc., 49, 357-370.

岡野憲太・末次大輔, 1989, マリアナ・スラブの下部マ ントル沈み込みについて WWSSN データを用いた $\mathrm{P}$ 波走時解析, 地震学会講演予稿集, No. 2, 90 .

Okino, K., M. Ando, S. Kaneshima and K. Hirahara, 1989, The horizontally lying slab, Geophys. Res. Lett., 16, 1059-1062.

Olson, P., 1984, An experimental approach to thermal convection in a two-layered mantle, J. Geophys. Res., 89, 11293-11301.

Paulssen, H., 1985, Upper mantle converted waves beneath the NARS array, Geophys. Res. Lett., 12, 709-712.

Paulssen, H., 1988, Evidence for a sharp 670-km discontinuity as inferred from P-to-S converted waves, J. Geophys. Res., 93, 10489-10500.

Regan, J. and D. L. Anderson, 1984, Anisotropic models of the upper mantle, Phys. Earth Planet. Interiors, 35, 227-263.

Revenaugh, J. and T. H. Jordan, 1987, Observations of first-order mantle reverberations, Bull. Seism. Soc. Am., 77, 1704-1717.

Revenaugh, J. and T.H. Jordan, 1989, A study of mantle layering beneath the western Pacific, J. Geophys. Res., 94, 5787-5813.

Richards, M. A. and C. W. Wicks, 1990, S-P conversion from the transition zone beneath Tonga and the nature of the $670 \mathrm{~km}$ discontinuity, Geophys. J. Int., 101, 1-35.

Richards, P. G., 1972, Seismic waves reflected from velocity gradient anomalies within the Earth's upper mantle, J. Geophys., 38, 517-527.

Richter, F. M., 1979, Focal Mechanisms and seismic energy release of deep and intermediate earthquakes in the Tonga-Kermadec region and their bearing on the depth extent of mantle flow, J. Geophys. Res., 84, 6783-6795.

Ringwood, A. E. and T. Irifune, 1986, Nature of the 650-km seismic discontinuity: implications for mantle dynamics and differentiation, Nature, 331, 131-136.

Schlittenhardt, J., J. Schweitzer and G. Muller, 1985, Evidence against a discontinuity at the top of D", Geophys. J. Roy. Astr. Soc., 81, 295-306.

Shimamura, H., H. Inatani, T. Asada, K. Suyehiro and T. Yamada, 1983, Longshot experiments to study velocity anisotropy in the oceanic lithosphere of the northwestern Pacific, Phys. Earth Planet. Interiors, 31, 348-362.

Silver, P. G. and W. W. Chan, 1986, Observations of body wave multipathing from broadband seismograms: Evidence for lower mantle slab penetration beneath the Sea of Okhotsk, J. Geophys. Res., 91, 13787-13802.

Silver, P. G., R. W. Carlson and P. Olson, 1988, Deep slabs, geochemical heterogeneity, and the large- scale structure of mantle convection: investigation of an enduring paradox, Ann. Rev. Earth Planet. Sci., 16, 477-541.

末次大輔, 1987 , スラブの下部マントル沈み込みについ ての最近の地震学的研究, 地震 $2,40,633-644$.

Suetsugu, D., 1989, Lower mantle high-velocity zone beneath the Kurils as inferred from P-wave travel time and amplitude data, J. Phys. Earth, 37, 265295.

Suetsugu, D. and I. NakAnishi, 1987, Regional and azimuthal dependence of phase velocities of mantle Rayleigh waves in the Pacific Ocean, Phys. Earth Planet, Interiors, 47, 230-245.

Sung, C. M. and R. G. Burns, 1976, Kinetics of highpressure phase transformations: implications to the evolution of the olivine-spinel transformation in the downgoing lithosphere and its consequences on the dynamics of the mantle, Tectonophysics, 31, 1-32.

TAKeI, Y. and D. Suetsugu, 1989, A high-velocity zone in the lower mantle under the Japan subduction zone inferred from precise measurements of P-wave arrival times, J. Phys. Earth, 37, 225-231.

竹下 徹・唐戸俊一郎, 1989, 岩石の塑性流動によって 形成された地球内部の異方性, 地震 $2,42,255-269$.

TANiмото, T., 1986, The Backus-Gilbert approach to the three-dimensional structure in the upper mantle, II, SH and SV velocity, Geophys. J. Roy. Astr. Soc., 84, 49-70.

Tалімото, T., 1987, The three dimensional shear wave structure in the mantle by overtone waveform inversion I. Radial seismogram inversion, Geophys. J. Roy. Astr. Soc., 89, 713-740.

Tалімото, T.,1990, Long wavelength S-wave velocity structure throughout the mantle, Geophys. J. Int., 100, 327-336.

TAnimoto, T. and D. L. Anderson, 1984, Mapping convection in the mantle, Geophys. Res. Lett., 11, 287-290.

TAnimoto, T. and D. L. Anderson, 1985, Lateral heterogeneity and azimuthal anisotropy of the upper mantle: Love and Rayleigh waves 100-250s, J. Geophys. Res., 90, 1842-1858.

VAssiliou, M. S. and B. H. HAger, 1988, Subduction zone earthquakes and stress in slabs, Pure Appl. Geophys. 128, 547-624.

Vidale, J.E., 1987 Waveform Effects of a highvelocity, subducted slab, Geophys. Res. Lett., 14, 542-545.

Vidale, J. E. and D. Garcia-Gonzalez, 1988, Seismic observation of a high-velocity slab $1200-1600 \mathrm{~km}$ in depth, Geophys. Res. Lett., 15, 369-372.

Weber, M., 1990, Subduction zones-their influence on traveltimes and amplitudes of P-waves, Geophys. J. Int., 101, 529-544.

Woodhouse, J. H. And A. M. Dziewonski, 1984, Mapping the upper mantle: three-dimensional modeling 
of earth structure by inversion of seismic waveforms, J. Geophys. Res., 89, 5953-5986.

Woodhouse, J.H. and A. M. Dziewonski, 1987, the three dimensional structure of the Earth, EOS Trans. Am. Geophys. Union, 68, 1210.

YounG, C. J. and T. LAY, 1987, The core-mantle boundary, Ann. Rev. Earth Planet. Sci., 15, 25-46. Zhou, H. W. and R. W. Clayton, 1990, P and S travel time inversions for subducting slab under the island arcs of the northwest Pacific, J. Geophys. Res., 95, 6829-6851. 